\title{
SKS splitting in the Western Indian Ocean from land and seafloor seismometers: Plume, plate and ridge signatures
}

\author{
John-Robert Scholz a,b,*, Guilhem Barruol a,b, Fabrice R. Fontaine a , Alessandro Mazzullo ${ }^{b}$, \\ Jean-Paul Montagner ${ }^{b}$, Eléonore Stutzmann ${ }^{b}$, Laurent Michon ${ }^{a}$, Karin Sigloch ${ }^{\mathrm{c}}$ \\ a Laboratoire GéoSciences Réunion, Université de La Réunion, Institut de Physique du Globe de Paris, Sorbonne Paris Cité, UMR CNRS 7154 , \\ F-97744 Saint-Denis, France \\ b Institut de Physique du Globe de Paris, Sorbonne Paris Cité, UMR7154 CNRS, France \\ c Earth Sciences Department, University of Oxford, South Parks Road, Oxford OX1 3AN, United Kingdom
}

\section{a b s tract}

We present SKS splitting measurements in the Western Indian Ocean, recorded on 20 land and 57 seafloor seismometers deployed by the RHUM-RUM experiment (Réunion Hotspot and Upper Mantle - Réunions Unterer Mantel). We discuss our splitting observations within their geodynamic settings and compare them to SKS splitting parameters predicted from an azimuthally anisotropic Rayleigh wave tomography model that includes the RHUM-RUM data. We find that anisotropic directions poorly correlate with the present-day motion of the Somali plate, which at $<2.6 \mathrm{~cm} / \mathrm{yr}$ may be too slow to cause strongly sheared fabric in the asthenosphere. Fast split directions $(\Phi)$ between La Réunion and the Central Indian Ridge (CIR) trend E-W and provide strong, first seismological evidence for near-horizontal flow in the asthenosphere that connects the Réunion mantle upwelling with the CIR, supporting a long-standing hypothesis on plume-ridge interaction. In the vicinity of the Réunion hotspot, we observe a seismic anisotropy pattern indicative of a parabolic asthenospheric flow controlled by the Réunion mantle upwelling and its consecutive asthenospheric spreading. We furthermore observe ridge-normal $\Phi$ along the CIR and ridge-parallel $\Phi$ along the Southwest Indian Ridge (SWIR), both mainly attributed to asthenospheric mantle flows. In the Mozambique Channel between East-Africa and Madagascar, we attribute E$\mathrm{W}$ trending $\Phi$ to frozen lithospheric structures, recording the paleo-orientation of the spreading ridges that enabled Madagascar's separation away from Africa. Based on the synopsis of this and previous SKS splitting studies at midocean ridges, we propose that ridge-normal $\Phi$ may develop at fast and intermediate spreading ridges (e.g., CIR and East Pacific Rise) and ridge-parallel $\Phi$ could be characteristic to slow spreading ridges (e.g., SWIR,' MidAtlantic Ridge and the paleo-ridges in the Mozambique Channel).

\section{Introduction}

The Réunion hotspot in the Western Indian Ocean feeds the Piton de la Fournaise, one of the most active volcanoes in the world. Its age-progressive hotspot track is formed by La Réunion Island, Mauritius Island and the Mascarene Plateau on the Somali plate, and the Chagos, Maldive and Laccadive alignment on the Indian plate (Duncan, 1990; Duncan et al., 1990). The track leads to the Deccan Traps of India, one of the largest flood basalt provinces on Earth that erupted 65 Ma ago (Courtillot et al., 1986) and is likely

\footnotetext{
* Corresponding author at: Laboratoire GéoSciences Réunion, Université de La Réunion, Institut de Physique du Globe de Paris, Sorbonne Paris Cité, UMR CNRS 7154, F-97744 Saint-Denis, France.

E-mail address: scholz@ipgp.fr (J.-R. Scholz).
}

linked to the Cretaceous-Paleogene extinction event (Richards et al., 2015).

The Western Indian Ocean presents an unusual variety of upper mantle phenomena to investigate. The Réunion volcanic hotspot has been proposed to be fed by a "primary" (Courtillot et al., 2003) mantle plume (Morgan, 1972) - a deep rooted upwelling of mantle material that may be connected to the South-African Superswell (Forte et al., 2010). A recent, regional Rayleigh wave tomography study indicates that the Réunion hotspot could also be an expression of mantle material rising from beneath the Mascarene Basin, where a broad low-shear wave velocity anomaly at asthenospheric depths is observed (Mazzullo et al., 2017). Morgan (1978) also hypothesized that some of the hot material rising beneath La Réunion may be feeding the nearest spreading ridge, the Central Indian Ridge (CIR) at $1000 \mathrm{~km}$ distance, through a sub-lithospheric, 
channeled mantle flow. The Southwest Indian Ridge (SWIR) is the other nearby spreading center. Despite its ultra-slow spreading rate and magma-starved dynamics, it also could be influenced by adjacent hotspots/plumes (La Réunion, Marion and/or Crozet; Sauter et al., 2009) and/or the South-African Superswell. Finally, in the regional context of the East African Rift System (EARS), the location of the diffuse plate boundary that connects the southern EARS to the SWIR remains subject to discussion (e.g., Kusky et al., 2010; Stamps et al., 2015), together with the synchronous volcanism occurring from the EARS to the Mascarene Basin at 10-20 Ma ago (Michon, 2016) that could suggest episodic, large-scale events of mantle upwelling.

To address these questions of upper mantle structures and dynamics, we analyzed seismic anisotropy via the splitting of the teleseismic, core-refracted shear waves such as SKS, SKKS, and pSKS phases (hereafter called XKS). Seismic anisotropy is accepted to result mostly from lattice preferred orientation (LPO) of rock-forming minerals in response to tectonic strain. In the upper mantle, olivine is the dominating phase. It is intrinsically anisotropic to $P$ and $S$-waves (e.g., Mainprice et al., 2000) and controls large-scale patterns of seismic anisotropy (Nicolas and Christensen, 1987). In the lithosphere, LPO may record past tectonic episodes that produced deformation such as faults and shear zones, tectono-thermal interactions with the asthenosphere such as plume head arrivals, and/or plate accretion at mid-ocean ridges (e.g., Wolfe and Silver, 1998). In the latter scenario, rock fabrics acquired through ridge-parallel or ridge-normal mantle flow (i.e., ridge-parallel or ridge-normal LPO) could become "frozen-in" by lithospheric cooling and preserved during the seafloor's entire lifetime. In the asthenosphere, LPO may reflect present-day mantle flow, the subducting of mantle slabs, the shearing caused by motion of the overlying plate, and/or the flow induced by rising plumes spreading horizontally beneath the lithosphere (Morgan et al., 1995). In addition to LPO (or "intrinsic" anisotropy), shape preferred orientation (SPO, or "extrinsic" anisotropy) can contribute to observed shear wave splitting patterns. SPO can be generated by (liquid filled) cracks, oriented melt pockets, dipping discontinuities, and/or fine layering (e.g., Wang et al., 2013).

Seismic anisotropy may be also present within the $D^{\prime \prime}$ layer in the lowermost mantle (e.g., Kendall and Silver, 1996), and this region is also sampled by XKS waves. There are, however, several seismological arguments why observed XKS splitting is dominantly caused by upper mantle anisotropy: i) XKS splitting parameters often display short-scale variations indicative of rather superficial causes of anisotropy (e.g., Alsina and Snieder, 1994); and ii) anisotropy measurements from XKS and (local) $S$-phases yield similar splitting parameters, putting an upper bound of $\delta t_{\text {lower_mantle }} \lesssim$ $0.2 \mathrm{~s}$ on the splitting contribution from the lower mantle (e.g., Vinnik et al., 1995; Savage, 1999; Long, 2009). XKS splitting is hence a suitable tool to investigate seismic anisotropy in the upper mantle.

\section{Data set}

Seismic data analyzed in this study were recorded during the RHUM-RUM experiment (Réunion Hotspot and Upper Mantle Réunions Unterer Mantel; Barruol and Sigloch, 2013). This FrenchGerman experiment in the Western Indian Ocean (Fig. 1) deployed 20 broadband, three-component land seismometers between 2011 and 2016, and 57 broad- and wideband, three-component oceanbottom seismometers (OBSs) between October 2012 and December 2013. Detailed station information is provided in the on-line supplements. Stähler et al. (2016) reported details on the OBS performances. The RHUM-RUM data-set is freely available at the RESIF seismological archive center (see Acknowledgements).

\section{Methodology}

We refer to our measurements as XKS splittings, meaning we recorded splitting mostly on SKS phases but occasionally on SKKS and $p S K S$ phases, too.

\subsection{Non-null and null splitting measurements}

As they travel through anisotropic media, seismic shear waves may split into two perpendicularly polarized fast and slow components (e.g., Savage, 1999). From the three-component seismic data, one can determine the azimuth of the fast split direction $(\Phi)$ that depends on the fabric's orientation in the anisotropic media, and the delay time $(\delta t)$ between the two split waves, related to both the strength of anisotropy and the path length within the anisotropic layers. Records of split seismic shear phases are generally referred to as "non-null" measurements. For non-null measurements of XKS phases, energy should be present on both the seismogram Q- and T-components.

Alternatively, a shear wave propagating through an anisotropic medium may not split if its initial polarization coincides with either the fast or slow splitting axis, or if splittings from multiple anisotropic layers cancel each other (e.g., two orthogonal anisotropic layers of equal strength and thickness). For XKS phases, such apparent no-splitting cases - called "null" measurements - should result in energy present only on the seismogram's Q-component. If one-layered anisotropy is present, eventbackazimuths of nulls should coincide with $\Phi$ of non-nulls (or be perpendicular to them). In case of two-layered anisotropy, one should observe apparent backazimuthal variations of both $\Phi$ and $\delta t$ with a $\pi / 2$-periodicity (e.g., Silver and Savage, 1994). In the case of real absence of anisotropy, no splitting occurs and should lead to only null measurements, regardless of the event-backazimuths. In the present study, we generally recorded more null measurements than non-null measurements from the data. This reflects the relatively small signal-to-noise ratios on the seafloor seismometers, particularly on the horizontal components. This, in turn, may hide the small amplitudes of split XKS phases on the T-components, requiring caution to not over-interpret these null measurements.

\subsection{Measuring splitting using SplitLab}

Prior to our splitting measurements, we oriented the horizontal components of the ocean-bottom seismometers (OBSs) using $P$-wave and Rayleigh wave polarizations of teleseismic earthquakes (Scholz et al., 2017). We used the MATLAB-based SplitLab toolbox (Wüstefeld et al., 2008, newest beta-version: https:// github.com/IPGP/splitlab) to measure null and non-null XKS splitting from teleseismic earthquakes of $M_{W} \geq 5.8$, with epicentral distances ranging $85-130^{\circ}$.

We used the eigenvalue approach of Silver and Chan (1991) to retrieve the strike angle of the fast split direction $(\Phi)$ defined clockwise from North, the delay time $(\delta t)$ between the two split waves, and their confidence regions corresponding to $2 \sigma$ (Wüstefeld et al., 2008, Appendix A). We chose to minimize the product $\lambda_{1} \cdot \lambda_{2}$, where $\lambda_{i}$ are the eigenvalues of the twodimensional covariance matrix in the L-Q plane. For an optimally constrained result of each event-station pair, SplitLab uses an automated quality factor to determine the best set of XKS phase window size, window location, and corner frequencies of band-pass filter (Wüstefeld and Bokelmann, 2007). Typically, we obtained good constraints for band-pass filters of $0.02-0.2 \mathrm{~Hz}$. 


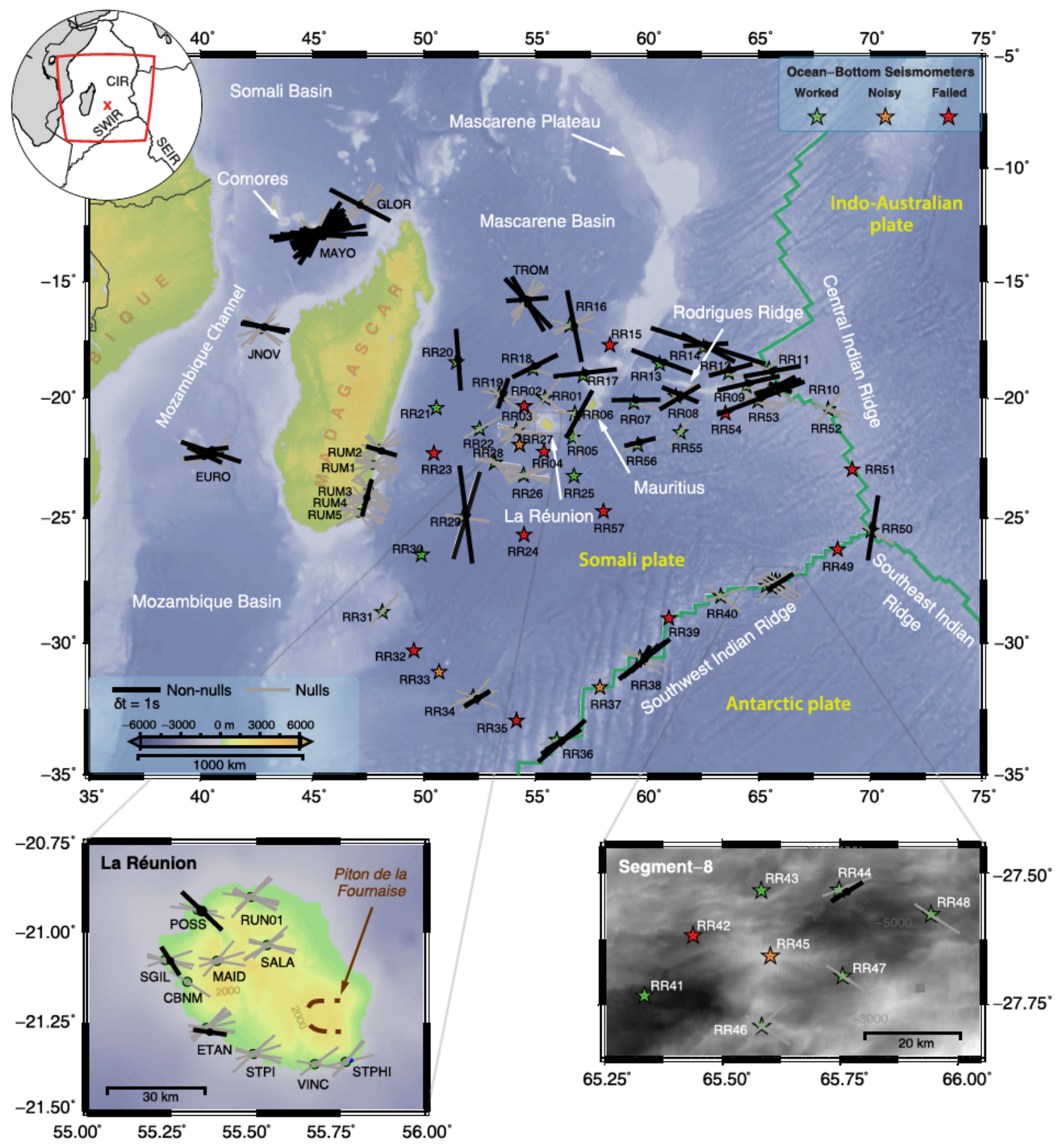

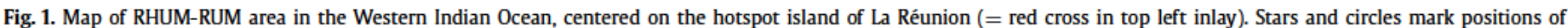

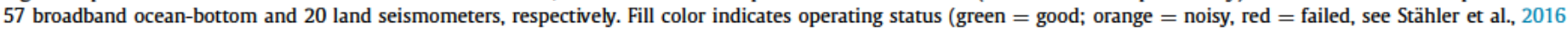

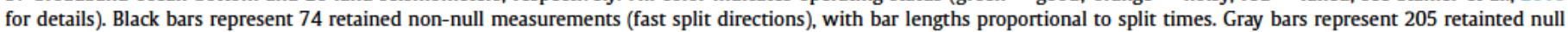

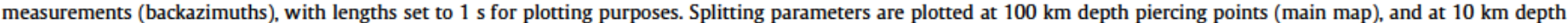

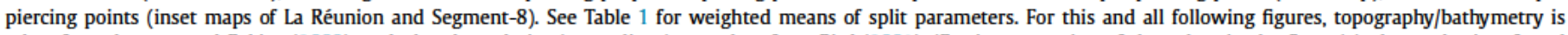

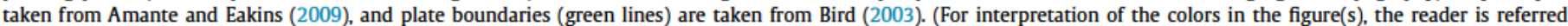
to the web version of this article.)

\subsection{Classifying, culling and averaging splitting measurements}

We automatically classified each measurement with a signalto-noise ratio $\geq 5.0$ into good, fair, goodNull, and fairNull, adopting the definitions of Wüstefeld and Bokelmann (2007). These criteria are based on measurements of terrestrial data, performing thus stricter on OBS data as these show higher seismic noise levels on all components compared to land seismometers. We subsequently revised each measurement, most notably the presence/absence of energy on the seismogram T-component and the general shape of the map of eigenvalues. We rejected all non-null splitting measurements with fast split direction errors $>20^{\circ}$. An example of a retained SKS splitting recorded on seafloor seismometer RR29 is shown in Fig. 2.

Station-wise for the retained measurements, we calculated the weighted (circular) means of $\Phi$ and $\delta t$ for non-null, and the weighted circular means of backazimuths for null measurements (Table 1). Errors of the mean $\Phi$ and $\delta t$ correspond to one weighted 
Table 1

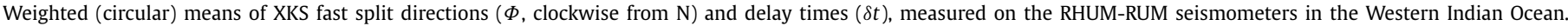

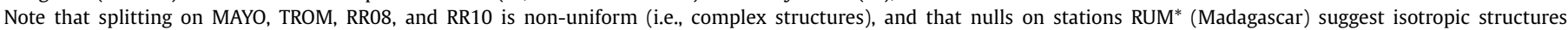

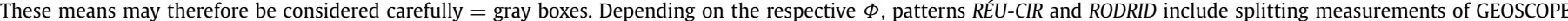

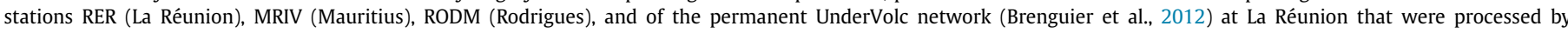

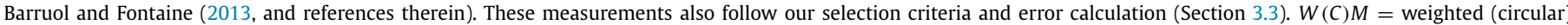

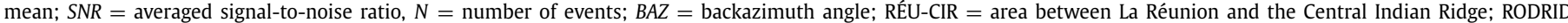
$=$ Rodrigues Ridge; SWIR = Southwest Indian Ridge; MOZCHA = Mozambique Channel.

\begin{tabular}{|c|c|c|c|c|c|c|c|c|c|c|c|}
\hline \multirow[t]{2}{*}{ Site } & \multicolumn{8}{|c|}{ Non-nulls } & \multicolumn{3}{|l|}{ Nulls } \\
\hline & $\begin{array}{l}\Phi_{W C M} \\
\left({ }^{\circ}\right)\end{array}$ & \pm & $\begin{array}{l}\Phi_{e r r} \\
\left(^{\circ}\right)\end{array}$ & $\begin{array}{l}\delta t_{W M} \\
(\mathrm{~s})\end{array}$ & \pm & $\begin{array}{l}\delta t_{e r r} \\
(\mathrm{~s})\end{array}$ & SNR & $N$ & $\begin{array}{l}B A Z_{W C M} \\
\left(^{\circ}\right)\end{array}$ & SNR & $N$ \\
\hline RR01 & - & & - & - & & - & - & - & 37 & 5.9 & 2 \\
\hline RR03 & - & & - & - & & - & - & - & 38 & 8.9 & 5 \\
\hline RR05 & - & & - & - & & - & - & - & 80 & 6.0 & 1 \\
\hline RR06 & 29 & \pm & 4 & 1.2 & \pm & 0.1 & 14.7 & 1 & 6 & 9.7 & 2 \\
\hline RR07 & 90 & \pm & 26 & 1.0 & \pm & 0.1 & 5.6 & 1 & 16 & 9.3 & 1 \\
\hline RR08 & 86 & \pm & 15 & 0.9 & \pm & 0.2 & 11.0 & 2 & 58 & 11.2 & 1 \\
\hline RR09 & 77 & \pm & 8 & 1.4 & \pm & 0.1 & 8.7 & 1 & 14 & 5.0 & 1 \\
\hline RR10 & 82 & \pm & 21 & 0.8 & \pm & 0.2 & 6.8 & 3 & 32 & 5.6 & 1 \\
\hline RR11 & 80 & \pm & 20 & 1.2 & \pm & 0.6 & 7.7 & 1 & 25 & 6.2 & 2 \\
\hline RR12 & 75 & \pm & 12 & 1.0 & \pm & 0.1 & 9.9 & 1 & 14 & 9.4 & 2 \\
\hline RR13 & 111 & \pm & 10 & 1.5 & \pm & 0.2 & 5.2 & 1 & - & - & - \\
\hline RR14 & 104 & \pm & 13 & 1.6 & \pm & 0.7 & 10.6 & 3 & 13 & 8.3 & 3 \\
\hline RR16 & 169 & \pm & 3 & 1.6 & \pm & 0.1 & 9.6 & 1 & 79 & 7.1 & 3 \\
\hline RR17 & 83 & \pm & 7 & 1.4 & \pm & 0.1 & 9.8 & 1 & - & - & - \\
\hline RR18 & 64 & \pm & 15 & 1.1 & \pm & 0.2 & 6.8 & 1 & 18 & 6.9 & 1 \\
\hline RR19 & 19 & \pm & 18 & 0.7 & \pm & 0.3 & 15.8 & 1 & 29 & 6.8 & 3 \\
\hline RR20 & 176 & \pm & 16 & 1.3 & \pm & 0.3 & 8.5 & 1 & - & - & - \\
\hline RR22 & - & & - & - & & - & - & - & 61 & 5.3 & 1 \\
\hline RR26 & - & & - & - & & - & - & - & 88 & 8.3 & 5 \\
\hline RR28 & - & & - & - & & - & - & - & 24 & 10.2 & 6 \\
\hline RR29 & 5 & \pm & 12 & 2.0 & \pm & 0.1 & 16.4 & 2 & 9 & 9.9 & 3 \\
\hline RR31 & - & & - & - & & - & - & - & 42 & 6.8 & 1 \\
\hline RR34 & 59 & \pm & 1 & 0.6 & \pm & 0.1 & 11.3 & 2 & 55 & 9.5 & 4 \\
\hline RR36 & 55 & \pm & 5 & 1.0 & \pm & 0.3 & 10.2 & 3 & 74 & 6.5 & 1 \\
\hline RR38 & 44 & \pm & 9 & 1.0 & \pm & 0.3 & 16.1 & 4 & 27 & 9.7 & 2 \\
\hline RR40 & - & & - & - & & - & - & - & 55 & 6.9 & 2 \\
\hline RR44 & 58 & \pm & 18 & 0.7 & \pm & 0.3 & 10.2 & 1 & 69 & 5.8 & 1 \\
\hline RR46 & - & & - & - & & - & - & - & 40 & 6.8 & 2 \\
\hline RR47 & - & & - & - & & - & - & - & 34 & 5.5 & 1 \\
\hline RR48 & - & & - & - & & - & - & - & 33 & 6.5 & 1 \\
\hline RR50 & 9 & \pm & 4 & 1.5 & \pm & 0.1 & 8.4 & 1 & 31 & 8.0 & 1 \\
\hline RR52 & - & & - & - & & - & - & - & 27 & 10.4 & 3 \\
\hline RR53 & 69 & \pm & 10 & 2.0 & \pm & 0.3 & 5.7 & 1 & 18 & 8.4 & 3 \\
\hline RR55 & - & & - & - & & - & - & - & 37 & 5.8 & 1 \\
\hline RR56 & 76 & \pm & 18 & 0.7 & \pm & 0.7 & 7.7 & 1 & 71 & 6.3 & 1 \\
\hline CBNM & - & & - & - & & - & - & 1 & 33 & 6.6 & 1 \\
\hline ETAN & 99 & \pm & 20 & 0.7 & \pm & 0.4 & 14.7 & 1 & 42 & 7.2 & 9 \\
\hline MAID & - & \pm & - & - & & - & - & - & 41 & 16.7 & 3 \\
\hline POSS & 134 & \pm & 20 & 0.6 & \pm & 1.0 & 8.8 & 1 & 12 & 98.2 & 2 \\
\hline RUN01 & - & & - & - & & - & - & - & 27 & 8.7 & 12 \\
\hline SALA & - & & - & - & & - & - & - & 28 & 8.4 & 8 \\
\hline SGIL & 147 & \pm & 16 & 0.7 & \pm & 0.2 & 8.8 & 1 & 6 & 7.6 & 5 \\
\hline STPHI & - & & - & - & & - & - & - & 49 & 12.6 & 3 \\
\hline STPI & - & & - & - & & - & - & - & 35 & 7.5 & 6 \\
\hline VINC & - & & - & - & & - & - & - & 76 & 15.6 & 2 \\
\hline EURO & 97 & \pm & 15 & 0.9 & \pm & 0.3 & 10.2 & 4 & 55 & 10.0 & 12 \\
\hline GLOR & 118 & \pm & 6 & 1.4 & \pm & 0.1 & 5.7 & 1 & 40 & 7.6 & 6 \\
\hline JNOV & 101 & \pm & 3 & 1.0 & \pm & 0.1 & 8.3 & 2 & 47 & 7.3 & 5 \\
\hline MAYO & 65 & \pm & 32 & 1.2 & \pm & 0.4 & 13.1 & 25 & 38 & 9.6 & 18 \\
\hline TROM & 125 & \pm & 27 & 1.2 & \pm & 0.2 & 7.9 & 3 & 38 & 6.8 & 5 \\
\hline RUM1 & - & 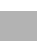 & - & - & 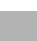 & - & - & - & 43 & 8.3 & 9 \\
\hline RUM2 & 107 & \pm & 20 & 0.7 & \pm & 0.9 & 14.3 & 1 & 48 & 14.0 & 8 \\
\hline RUM3 & - & & - & - & & - & - & - & 43 & 6.4 & 5 \\
\hline RUM4 & 15 & \pm & 14 & 0.8 & \pm & 0.2 & 5.3 & 1 & 46 & 6.8 & 8 \\
\hline RUM5 & - & & - & - & & - & - & - & 57 & 7.1 & 11 \\
\hline \multicolumn{12}{|l|}{ Pattern } \\
\hline RÉU-CIR & 79 & \pm & 27 & 1.1 & \pm & 0.3 & 8.5 & 41 & 32 & 11.7 & 500 \\
\hline RODRID & 106 & \pm & 10 & 1.3 & \pm & 0.6 & 9.4 & 7 & 21 & 8.1 & 11 \\
\hline SWIR & 50 & \pm & 10 & 1.0 & \pm & 0.3 & 13.2 & 8 & 45 & 7.1 & 10 \\
\hline MOZCHA & 70 & \pm & 37 & 1.2 & \pm & 0.4 & 12.2 & 32 & 33 & 9.1 & 41 \\
\hline
\end{tabular}


(a)

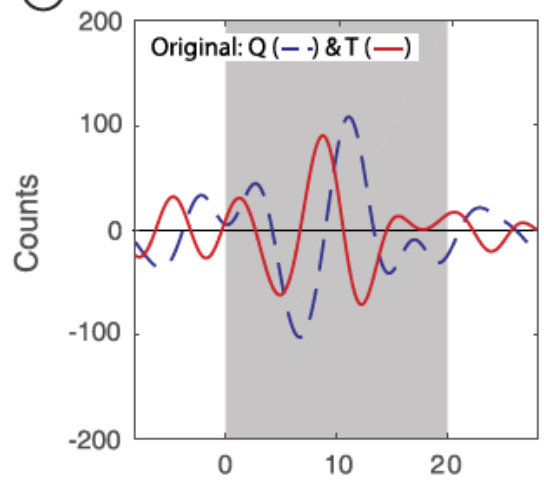

(C)

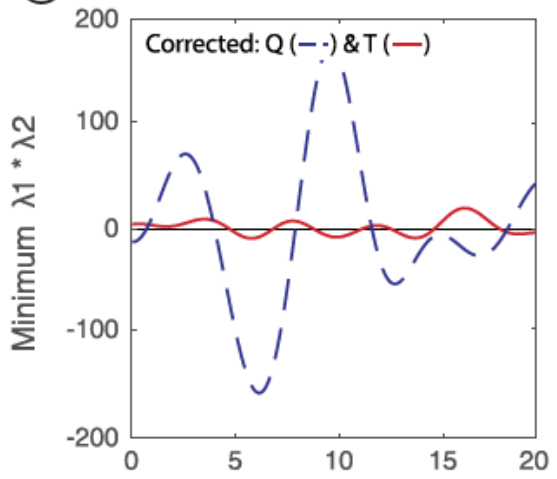

(b)

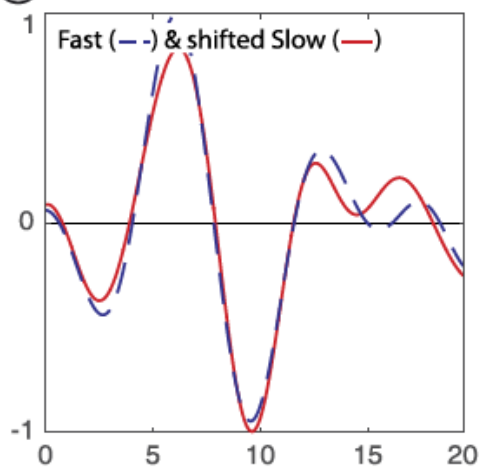

(d)

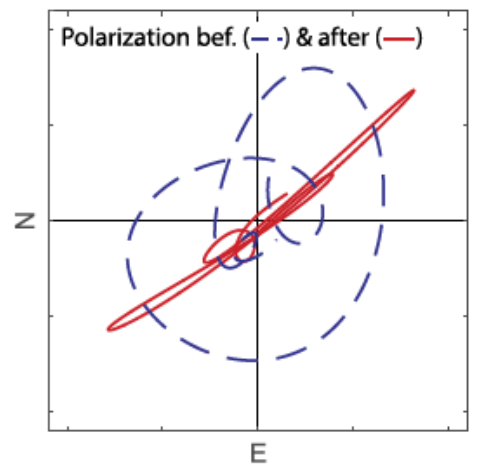

Event:

2013-05- $14 ; 42.71^{\circ} \mathrm{N}$

$131.10^{\circ} \mathrm{E} ; d=562 \mathrm{~km}$

$M w=6.3$

Station:

$\mathrm{RR} 29 ; \mathrm{BAZ}=64.4^{\circ}$

$\Delta=11,058 \mathrm{~km}\left(99.4^{\circ}\right)$

Measurement: Phase: SKS ; SNR=12.1

Filter: $0.05 \mathrm{~Hz}-0.15 \mathrm{~Hz}$

Quality: good

Fast split axis: $\quad-7^{\circ} \pm 6^{\circ}$

Split time: $\quad 2.1 \mathrm{~s} \pm 0.1 \mathrm{~s}$

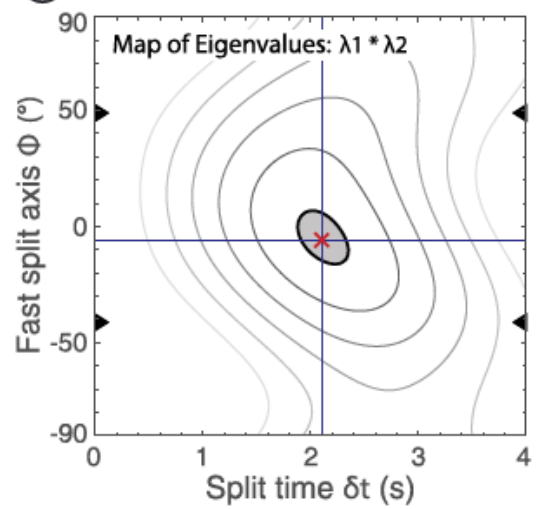

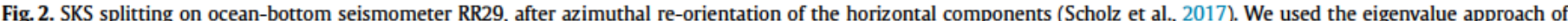

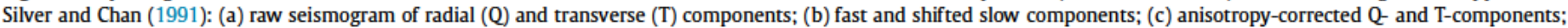

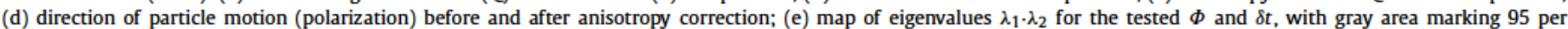

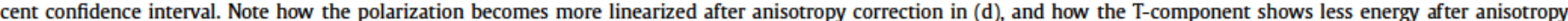
correction in (c) than in the original seismogram in (a).

angular deviation, and one weighted linear standard deviation, respectively. In cases with only one measurement, errors are those of individual measurements. Weight factors depend on the measurements' assigned quality: weight $_{\text {good }}=1$, weight $t_{\text {fair }}=0.7$, weight $_{\text {goodNull }}=1$, and weight $_{\text {fairNull }}=0.7$.

\subsection{Predicting splitting parameters from Rayleigh waves}

The azimuthally anisotropic, regional Rayleigh wave tomography by Mazzullo et al. (2017) integrated RHUM-RUM's seismic data. This model defines isotropic shear wave velocities $(V s 0)$ and azimuthal anisotropies for each degree in latitude and longitude and each $5 \mathrm{~km}$ in depth, down to depths of $350 \mathrm{~km}$. We used these azimuthal anisotropies to predict XKS splitting parameters ( $\Phi_{\text {pred }}$ and $\delta t_{\text {pred }}$ ) for the events that provided non-null measurements, following the $n$-layer algorithm of Silver and Savage (1994) that estimates $\Phi_{\text {pred }}$ and $\delta t_{\text {pred }}$ for given $\Phi_{n}$ and $\delta t_{n}$ in $n$ layers, and using formulas of Montagner et al. (2000) that relate the model's azimuthal anisotropy parameters to $\Phi_{n}$ and $\delta t_{n}$. Generally, the expectation is that tomography-predicted split times are smaller than XKS-measured split times, as the surface wave model's lateral resolution may be $\sim 500 \mathrm{~km}$ and therefore much larger than that of XKS waves with Fresnel zone radii of $40-60 \mathrm{~km}$ at depths of $100-200 \mathrm{~km}$. We further used the surface wave tomographic model to define the lithosphere-asthenosphere boundary (LAB) as the depth at which the Vs0-gradient with respect to depth minimizes (Burgos et al., 2014). This allows us to not only predict XKS splitting parameters for the crust-upper mantle (depth: 1-350 km), but also to compute their respective lithospheric ( $1 \mathrm{~km}$ down to the $\mathrm{LAB}$ ) and asthenospheric (LAB down to $350 \mathrm{~km}$ ) contributions. We listed details on this approach in the supporting material, including a comparison between tomography-derived and observed XKS split parameters (Fig. S1).

\section{Results and interpretation}

20 land seismometers and 40 usable ocean-bottom seismometers (OBSs) yielded 74 non-null and 205 null XKS splitting measurements from 101 earthquakes (Fig. 1). The signal-to-noise ratio for all these measurements averages 9.9, the dominant frequency $0.1 \mathrm{~Hz}$. The smallest earthquake magnitudes yielding splitting were $M_{W}=6.1$ on land station MAYO, and $M_{W}=6.3$ on OBS RR29 (Fig. 2). Individual measurements can be found in the supporting material and in our on-line XKS splitting data-base (Wüstefeld et al., 2009; see Acknowledgements for links). Weighted means of fast split directions $(\Phi)$, delay times $(\delta t)$, and backazimuths of nulls are listed in Table 1.

Our results show a high degree of regional variability, hence we group our interpretations into geodynamic regions. To enable discussions on anisotropy location and origin, we compare observed XKS splitting parameters to predicted XKS splitting parameters computed from the azimuthally anisotropic, regional Rayleigh wave tomography of the RHUM-RUM area (Mazzullo et al., 2017). In Table 2, we summarize our interpretations and compare them to those of previous XKS studies at mid-ocean ridges and oceanic hotspots. Table 2 therefore acts as a review of literature, too. 
Table 2

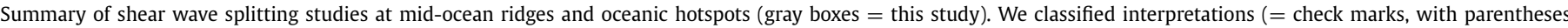

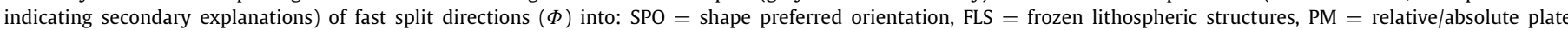

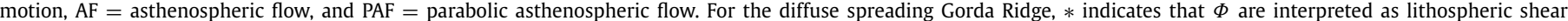

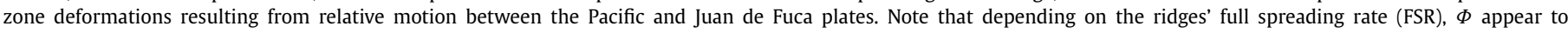

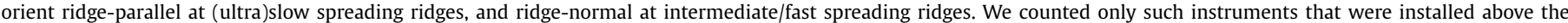

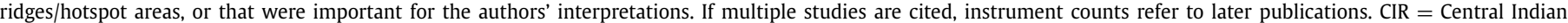

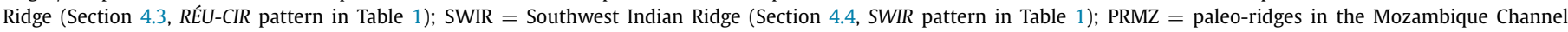
(Section 4.5, MOZCHA pattern in Table 1); MAR = Mid-Atlantic Ridge. TS = terrestrial seismometers; OBS = ocean-bottom seismometers.

\begin{tabular}{|c|c|c|c|c|c|c|c|c|c|c|}
\hline \multicolumn{3}{|l|}{ Site } & \multirow[t]{2}{*}{ Instruments } & \multirow{2}{*}{$\frac{\text { Observation }}{1 \text { st order } \Phi}$} & \multicolumn{5}{|c|}{ Interpretation } & \multirow[t]{2}{*}{ References } \\
\hline & $\begin{array}{l}\text { Ridge FSR } \\
(\mathrm{cm} / \mathrm{yr})\end{array}$ & Hotspot & & & $\mathrm{SPO}$ & FLS & PM & $\mathrm{AF}$ & $\mathrm{PAF}$ & \\
\hline French Polynesia & - & $\checkmark$ & $16 \mathrm{TS}, 9 \mathrm{OBS}$ & $\mathrm{N} 125^{\circ} \mathrm{E}$ & - & $\checkmark^{1}$ & $\checkmark^{1}$ & - & $\checkmark^{2}$ & $\begin{array}{l}{ }^{1} \text { Fontaine et al., } 2007 \\
{ }^{2} \text { Barruol et al., } 2009\end{array}$ \\
\hline Hawaiian Islands & - & $\checkmark$ & $15 \mathrm{TS}, 46 \mathrm{OBS}$ & $\mathrm{N} 075^{\circ} \mathrm{E}$ & - & $\checkmark^{1,2}$ & $\checkmark^{1}$ & - & $\checkmark^{1},-^{2}$ & $\begin{array}{l}{ }^{1} \text { Walker et al., } 2001 \\
{ }^{2} \text { Collins et al., } 2012\end{array}$ \\
\hline La Réunion & - & $\checkmark$ & 35 TS, 6 OBS & $\mathrm{N} 086^{\circ} \mathrm{E}$ & - & - & $\checkmark^{1}$ & $\checkmark^{2}$ & $\checkmark^{1,2}$ & $\begin{array}{l}{ }^{1} \text { Barruol and Fontaine, } 2013 \\
{ }^{2} \text { This study }\end{array}$ \\
\hline Galápagos & - & $\checkmark$ & $11 \mathrm{TS}$ & $\mathrm{N} 095^{\circ} \mathrm{E}$ & $(\checkmark)$ & - & $\checkmark$ & - & - & Fontaine et al., 2005 \\
\hline East Pacific Rise & 15.0 & - & $61 \mathrm{OBS}$ & $\perp$ ridge-axis & $(\checkmark)^{2}$ & - & $\checkmark^{1}$ & $\checkmark^{1,2}$ & - & $\begin{array}{l}{ }^{1} \text { Wolfe and Solomon, } 1998 \\
{ }^{2} \text { Harmon et al., } 2004\end{array}$ \\
\hline Gorda & 6.5 & - & 16 OBS & $\perp$ ridge-axis & - & $* 1$ & $* 1$ & $\checkmark^{2}$ & - & $\begin{array}{l}{ }^{1} \text { Bodmer et al., } 2015 \\
{ }^{2} \text { Martin-Short et al., } 2015\end{array}$ \\
\hline Juan de Fuca & 6.0 & - & 11 OBS & || ridge-axis & - & - & $\checkmark^{2}$ & $\checkmark^{1}$ & - & $\begin{array}{l}{ }^{1} \text { Bodmer et al., } 2015 \\
{ }^{2} \text { Martin-Short et al., } 2015\end{array}$ \\
\hline CIR & 4.5 & - & 3 OBS & $\perp$ ridge-axis & - & $(\checkmark)$ & $(\checkmark)$ & $\checkmark$ & - & This study \\
\hline PRMZ & 3.0 & - & $4 \mathrm{TS}$ & || ridge-axis & - & $\checkmark$ & - & - & - & This study \\
\hline Iceland / MAR & 2.0 & $\checkmark$ & $43 \mathrm{TS}$ & || ridge-axis & $(\checkmark)^{2}$ & - & $\checkmark^{1}$ & $\checkmark^{1,2}$ & - & $\begin{array}{l}{ }^{1} \text { Bjarnason et al., } 2002 \\
{ }^{2} \mathrm{Li} \text { and Detrick, } 2003\end{array}$ \\
\hline SWIR & 1.2 & - & 14 OBS & || ridge-axis & $(\checkmark)$ & $(\checkmark)$ & - & $\checkmark$ & - & This study \\
\hline
\end{tabular}

\subsection{La Réunion}

The 10 RHUM-RUM land seismometers on La Réunion Island were installed for 2.5 years on average. Despite this long recording period, we obtained only 3 non-null but 51 null measurements (Fig. 3a). Such paucity of non-null measurements had been noticed before by Barruol and Fontaine (2013, and references therein). Like Barruol and Fontaine (2013), we measured anisotropy exclusively via events from two distinct backazimuth ranges $(B A Z=$ $\mathrm{N} 040-070^{\circ} \mathrm{E}$ and $\mathrm{N} 100-110^{\circ} \mathrm{E}$ ), whilst event-backazimuths of nulls show no preferred orientation (supplement Fig. S2). Such complexity may result from the signature of deep source(s) of anisotropy such as in the $D^{\prime \prime}$ layer that could affect the XKS phases (e.g., Hall et al., 2004). The backazimuthal variations illustrated in Fig. S1 (electronic supplement) may also be explained by more local lateral heterogeneity in the upper mantle beneath La Réunion, characterized by anisotropy present along a few particular directions with the remaining azimuths being isotropic to XKS waves.

Among our three splittings, two of them strike $\sim \mathrm{NW}-\mathrm{SE}$ in the north of La Réunion, and one strikes $\sim \mathrm{E}-\mathrm{W}$ in the south. The latter is fully compatible with the anisotropic pattern previously noted by Barruol and Fontaine (2013) around the volcano Piton de la Fournaise (Fig. 3a), and, as shown in the next section, fully compatible with our observations made further east that may sign a nearhorizontal, asthenospheric mantle flow towards the Central Indian Ridge. Nevertheless, we cannot preclude possible contributions of lithospheric anisotropy.

Interpreting the two splittings in the island's north is more ambiguous. If one admits that short-scale variations in the asthenospheric anisotropy are unlikely for such small-scale island of 45 $\times 70 \mathrm{~km}^{2}$, these splitting observations trending NW-SE (Fig. 3a) may either reveal lower mantle anisotropy or different lithospheric anisotropy in the North than in the South. Although the first case cannot be rejected, it appears unlikely as both we and Barruol and Fontaine (2013) measured similar fast split directions from different backazimuths and hence different parts of the lower mantle and/or $D^{\prime \prime}$. On the other hand, seismological observations indicate complex lithospheric structure beneath La Réunion that may explain such short-scale variation. The 60 Myrs old lithosphere
(Müller et al., 2008) extends indeed as deep as $\sim 70 \mathrm{~km}$ (Fontaine et al., 2015). It has been affected by the successive formation of two volcanic massifs over the last 10 Myrs (Michon et al., 2007) and is located almost above a paleo triple junction as indicated by magnetic anomalies (Bissessur, 2011). These observations all advocate for strong lateral variations within the island's lithosphere, providing thus some possible explanation of the observed fast split directions and of the paucity of non-null measurements.

\subsection{Mascarene basin}

Our XKS splitting measurements in the Mascarene Basin (Fig. 3b) reveal two distinct characteristics. First, we observe dominant $\sim \mathrm{N}-\mathrm{S}$ trends in $\Phi$ on OBS RR16, RR20, RR29 and on island station TROM, all of which being located at distances $>500 \mathrm{~km}$ from La Réunion Island ("far-field" stations). Second, on OBS RR19, RR18, and RR17, which were deployed $\sim 250 \mathrm{~km}$ northwest to northeast of La Réunion ("near-field" stations), we observe an apparent rotation of $\Phi$ from $\mathrm{N} 019^{\circ} \mathrm{E}$ to $\mathrm{N} 084^{\circ} \mathrm{E}$, together with an increase of $\delta t$ from $0.7 \mathrm{~s}$ to $1.4 \mathrm{~s}$. Although we obtained only one non-null splitting on all these stations (Table 1), the two patterns are still significant, given the agreement especially amongst the far-field stations and that our recorded nulls strike fairly parallel (or perpendicular) to the observed $\Phi$, which is overall consistent. At the other near-field stations deployed S-to-SE of La Réunion (RR05, RR26, and RR28), we recorded only nulls, suggesting either an isotropic upper mantle, or, more likely, complex interaction between the lithosphere and the asthenospheric anisotropies.

Anisotropy may reside within the oceanic lithosphere and can be caused by fossil accretion at mid-ocean ridges (frozen lithospheric structures). Magnetic anomalies in this region indicate a particularly complex lithospheric structure within the Mascarene Basin surrounding La Réunion, including the presence of paleoridges and a paleo triple junction close to La Réunion Island (Bissessur, 2011). If the paleo-spreading ridges were intermediate to fast spreading, then the olivine $a$-axis of the accreted seafloor and therefore $\Phi$, would presumably be oriented normal to the ridge axis (as e.g. at the East Pacific Rise, Wolfe and Solomon, 1998; Harmon et al., 2004) and hence normal to the magnetic 
(a)

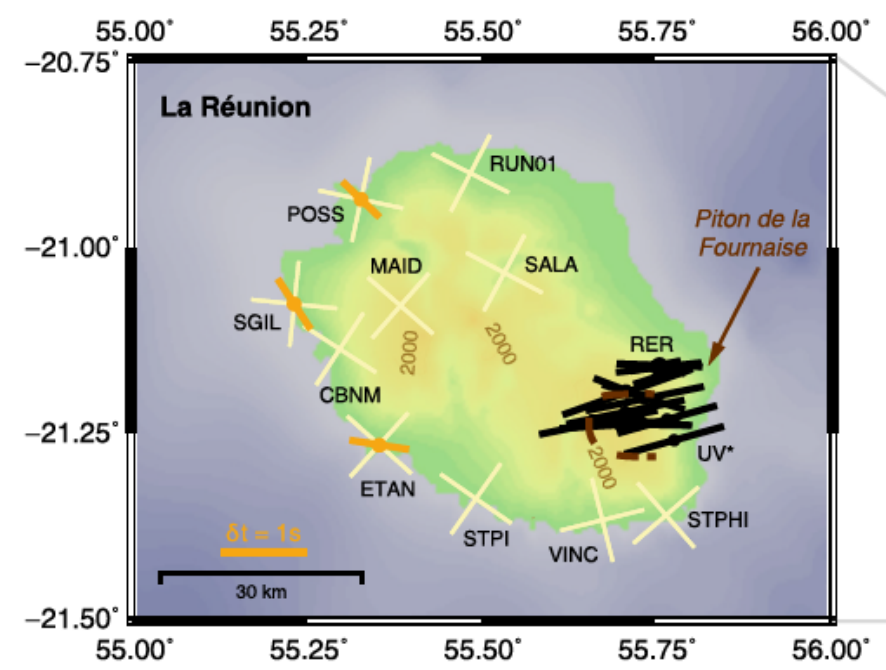

(b)

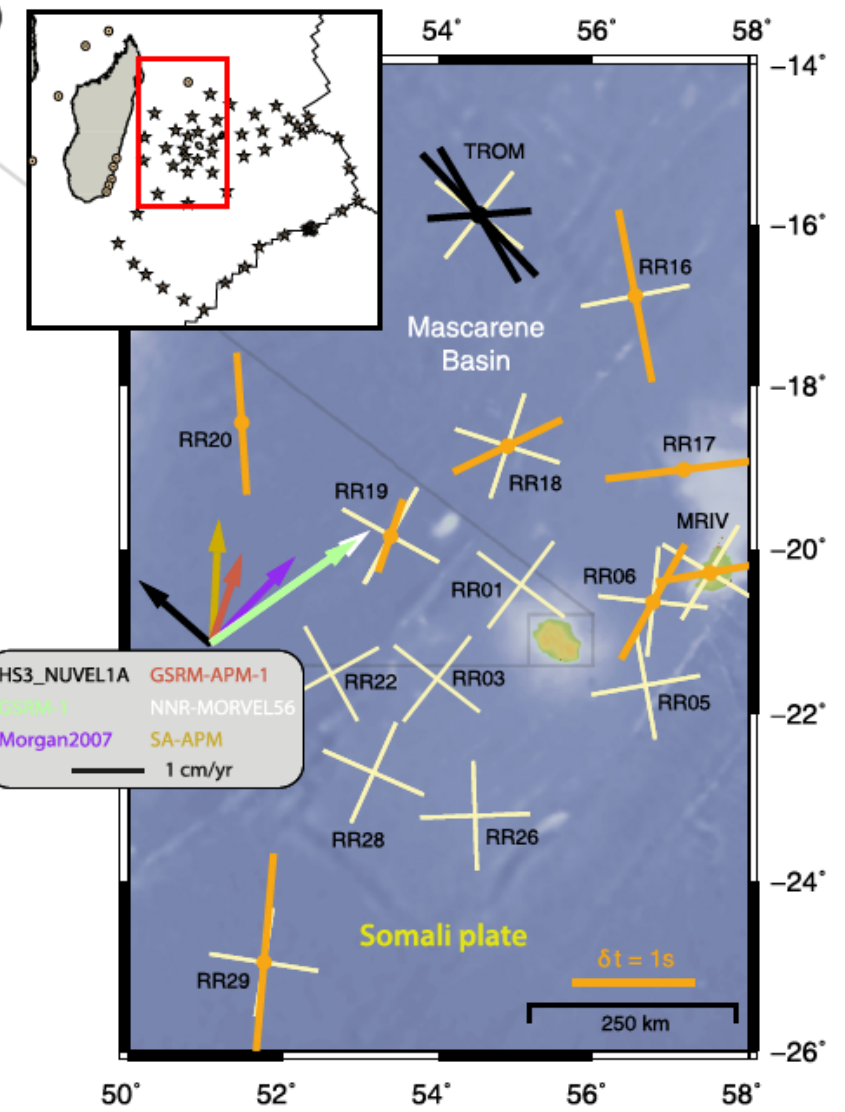

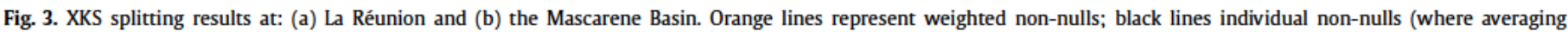

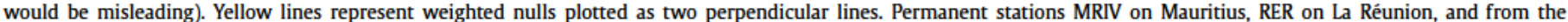

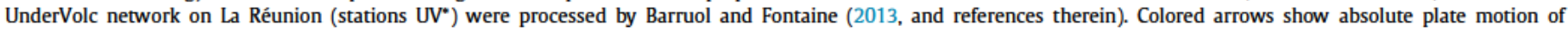
Somali plate according to various models, of magnitudes $<2.6 \mathrm{~cm} / \mathrm{yr}$.

seafloor isochrons. Indeed, $\Phi$ of both near-field and far-field stations in the Mascarene Basin strike fairly normal to the magnetic isochrons of the fossil Mascarene spreading ridge that predated the $\mathrm{CIR}$ in this region, suggesting dominant lithospheric anisotropy.

Predicted XKS splitting in the lithospheric column beneath the Mascarene Basin as extracted from surface wave tomography (Mazzullo et al., 2017), however, yield split times of $\delta t_{\text {pred_lithos }} \leq$ $0.5 \mathrm{~s}$ and $\mathrm{N}-\mathrm{S}$ trends that agree thus only with the trend at farfield stations and less with the rotation in $\Phi$ amongst the nearfield stations (Fig. 3b). This suggests that lithospheric anisotropy contributions due to frozen lithospheric structures are probably not the only cause of anisotropy beneath the Mascarene Basin.

At asthenospheric depths, tomography-derived XKS predictions show $\sim \mathrm{NE}-\mathrm{SW}$ trending $\Phi$ and split times of $\delta t_{\text {pred_asthenos }} \leq$ $0.5 \mathrm{~s}$. These predictions are consistent with our observations only at RR18 (Fig. 3b). We tested various plate motion models that may cause $\Phi$ to align parallel to the plate motion vectors: HS3-NUVEL1A (Gripp and Gordon, 2002), GSRM-1 (Kreemer et al., 2003), Morgan2007 (Morgan and Morgan, 2007), GSRM-APM-1 (Kreemer, 2009), NNR-MORVEL56 (Argus et al., 2011), and SA-APM (Becker et al., 2015) (Fig. 3b, colored arrows). Only the models of GSRM-1, Morgan2007, and NNR-MORVEL56 suggest $\sim$ NE-SW anisotropy and hence a decent agreement with our near-field stations, but these models do not explain the rotating $\Phi$ among these stations. For the plate models, the absolute plate velocity is low $(<2.6 \mathrm{~cm} / \mathrm{yr})$. The induced asthenospheric (azimuthal) anisotropy is therefore expected to be weak (Tommasi, 1998; Debayle et al., 2016) and could hardly explain the measured split times of $\delta t \approx 1.2 \mathrm{~s}$. Thus, neither frozen lithospheric structures nor the drag of the Somali plate can solely explain our observations.
An additional cause is suggested by the Rayleigh wave tomography of Mazzullo et al. (2017) that evidences a broad zone of low $S$-wave velocity anomalies beneath the entire Mascarene Basin, from directly below the lithosphere down to at least $300 \mathrm{~km}$ depth. Interpreted as anomalously hot asthenosphere, possibly plumederived, this material may be spreading horizontally in eastern direction and possibly feeding the CIR (see Section 4.3). Such material transport in the asthenosphere, combined with fossil lithospheric structures and perhaps minor contributions from the drag of the Somali plate could jointly explain the complex anisotropy beneath the Mascarene Basin.

\subsection{Central Indian and Rodrigues Ridges}

Along the Central Indian Ridge (CIR) due east of La Réunion Island, the Somali and Indo-Australian plates spread apart with intermediate rates of $\sim 6 \mathrm{~cm} / \mathrm{yr}$ at our instrumented segment between the Marie Celeste and Egeria Fracture Zones (Fig. 4a). This CIR segment is shifted $\sim 300 \mathrm{~km}$ westward relative to CIR segments further north and south (Fig. 4a), which was one of the reasons that led Morgan (1978) to postulate the Réunion hotspot had remained connected with the eastward-moving CIR, via (focused) asthenospheric mantle flow from the postulated Réunion mantle plume to this nearest ridge segment. Striking close to this projected line of interaction, the aseismic Rodrigues Ridge is an elongated bathymetric high (Fig. 4a), which according to Morgan (1978) could indicate magmatic leakage of the asthenospheric flow below.

The area between La Réunion and the CIR was instrumented by numerous RHUM-RUM OBSs and reveals two patterns in $\Phi$ (Fig. 4a, 


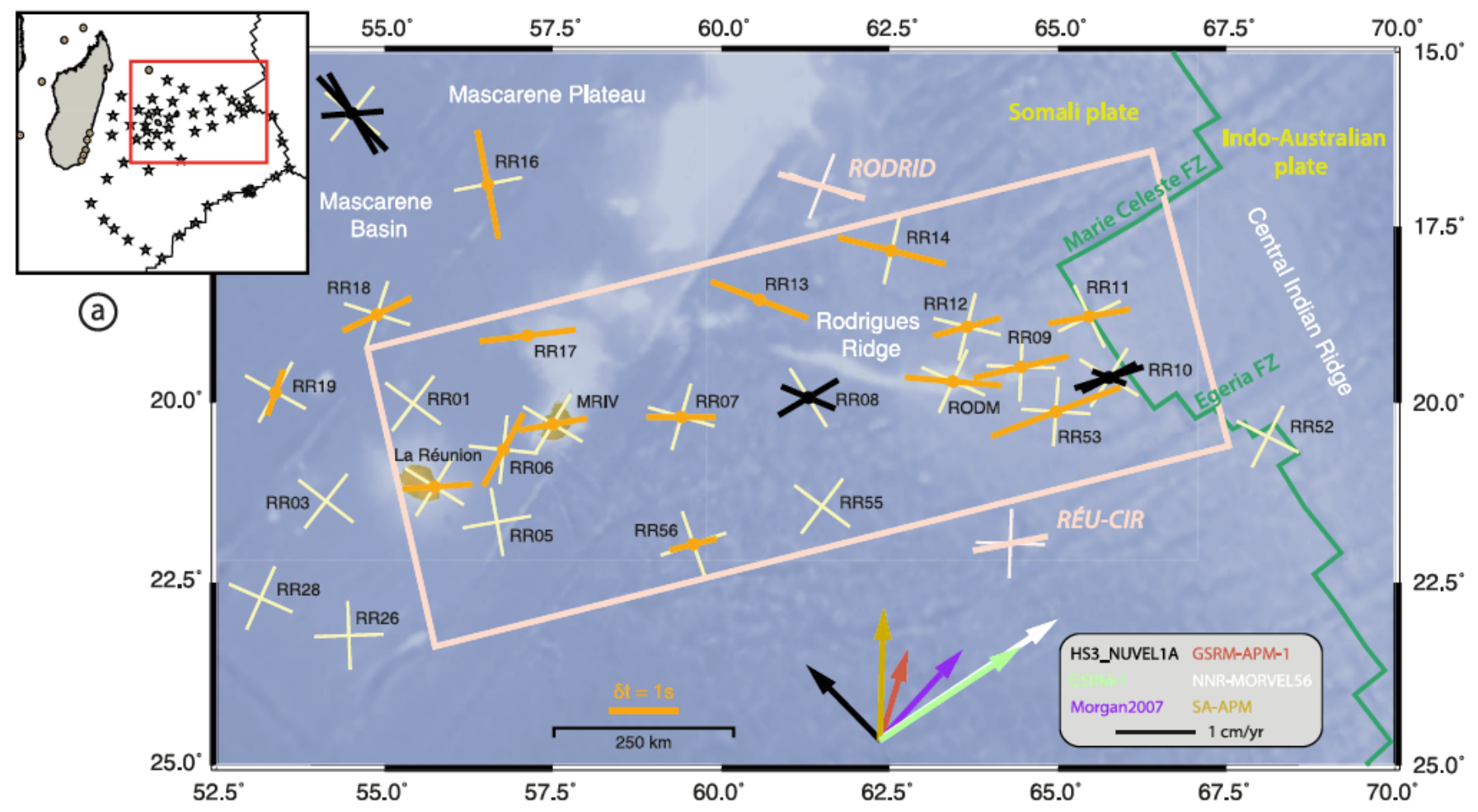

(b)

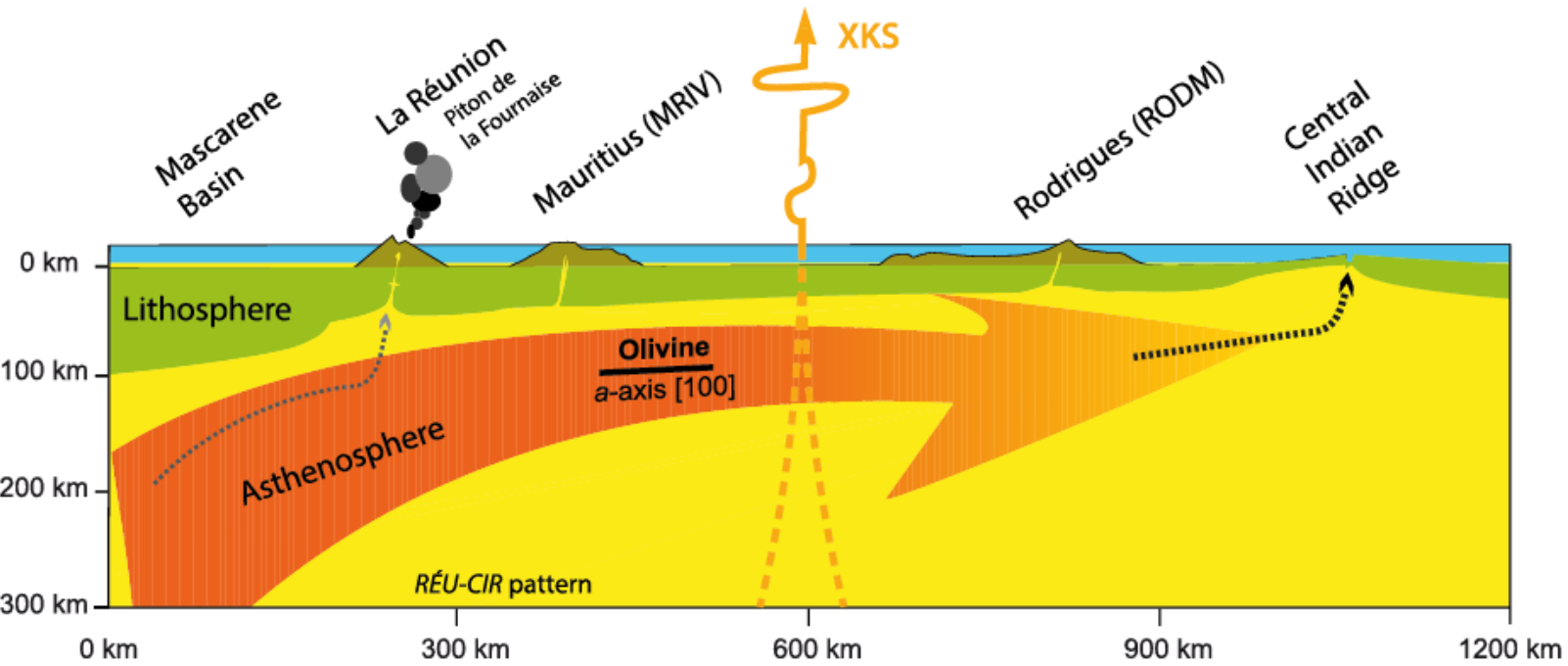

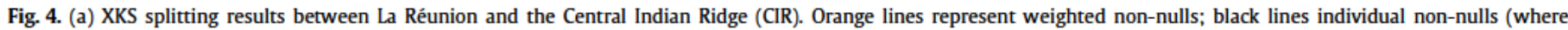

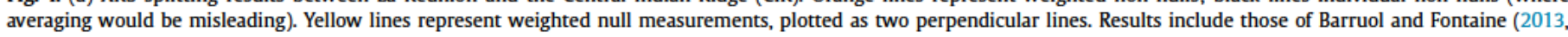

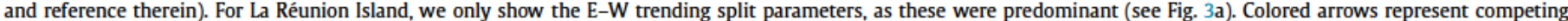

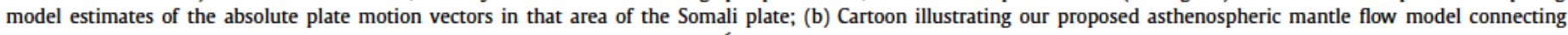
the mantle upwelling beneath La Réunion with the CIR at $1000 \mathrm{~km}$ distance (REU-CIR anisotropy pattern in Table 1).

red box). The first strikes on average $\mathrm{N} 079^{\circ} \mathrm{E}$ and thus parallel to a line connecting La Réunion and the CIR (pattern RÉU-CIR in Table 1). It consists of 41 non-null and 500 null measurements, including 29 and 433, respectively, of Barruol and Fontaine (2013) from the islands of La Réunion and Mauritius. Many stations in the area yielded at least one such 'connecting' measurement, suggesting robust and coherent anisotropic structure. For the OBSs close to the CIR, $\Phi$ strike on average normal to the ridge-axis with the exception of one measurement at OBS RR10, where $\Phi$ strikes parallel to the Rodrigues Ridge, suggesting a local complexity. The second pattern of anisotropy strikes on average $N 106^{\circ} \mathrm{E}$, i.e., parallel to the Rodrigues Ridge (pattern RODRID in Table 1). It consists of 7 non-null and 11 null measurements, including 1 and 7 data, respectively, of Barruol and Fontaine (2013) from the island of Rodrigues. For both trends, the backazimuths of null measurements generally comply with the dominant fast split directions observed.

Again, we consider the two likely causes of anisotropy: (i) frozen lithospheric structures due to the CIR's paleo-spreading direction, and (ii) asthenospheric anisotropy due to Somali plate drag. Concerning a frozen lithospheric origin of anisotropy, our idea is that a prominent lithospheric thinning from $\mathrm{W}$ to $\mathrm{E}$, i.e. lithospheric thinning from La Réunion towards the CIR (Fontaine et al., 2015), may in first order produce a consistent decrease of $\delta t$ from $\mathrm{W}$ to $\mathrm{E}$, for which we find no evidence. Although this deduction may be countered with respect to our obtained errors in $\delta t$ (Table 1), we moreover argue that a purely lithospheric 
anisotropy could not easily explain the two different anisotropic trends. As for asthenospheric anisotropy due to the Somali plate drag, neither of the tested plate motion models can simultaneously explain both anisotropic trends (Fig. 4a, colored arrows). Also, if present, the drag-induced anisotropy would probably be minor because the Somali plate is moving slowly $(<2.6 \mathrm{~cm} / \mathrm{yr})$. The predicted $\delta t$ therefore should be much smaller (Tommasi, 1998; Debayle et al., 2016) than our observations of $\delta t \approx 1.2$ s. Hence, seismic anisotropy due to frozen lithospheric structures or asthenospheric shearing at the Somali plate base may both be present in the region but contribute only minorly to our observations.

Instead, we favor that the Réunion/CIR connecting pattern (pattern $R E ́ U-C I R$, Fig. 4a) of XKS splitting may result from an active asthenospheric flow of material that rose beneath the Réunion hotspot and moves towards the CIR at $1000 \mathrm{~km}$ distance, as first proposed by Morgan (1978). Along this path from W to E, Fontaine et al. (2015) used receiver functions to constrain the lithospheric thickness to be $\sim 70 \mathrm{~km}$ beneath La Réunion, $\sim 50 \mathrm{~km}$ beneath Mauritius, and $\sim 25 \mathrm{~km}$ beneath Rodrigues. Such lithospheric thinning could facilitate sub-lithospheric mantle flow driven by its own buoyancy. For the Rodrigues Ridge-parallel XKS pattern (pattern RODRID, Fig. 4a), we likewise propose an $\sim \mathrm{W}$-E directed upper mantle flow at asthenospheric depths to explain the observations. Since this trend is observed at stations close to the Rodrigues Ridge itself (RR08, RR13, and RODM) but also at RR14 more than $200 \mathrm{~km}$ north, we conjecture that this trend is not produced by a focused ('pipeline') flow channel located directly beneath the Rodrigues Ridge. Instead, we suggest that hot mantle residing beneath the Mascarene Basin west of the Mascarene Plateau (as seen by Rayleigh wave tomography, Mazzullo et al., 2017, Section 4.2) is injected into the asthenosphere, resulting in an asthenospheric flow towards the CIR, at least partly driven by its own buoyancy. In the vicinity of the CIR, this asthenospheric flow may interfere and join the asthenospheric flow arriving from beneath La Réunion.

The delay times of both XKS splitting patterns average $\delta t_{R E U-C I R}$ $=1.1 \mathrm{~s}$ and $\delta t_{R O D R I D}=1.3 \mathrm{~s}$, respectively. The effective thicknesses of the respective asthenospheric flows may therefore range $d_{\text {REU-CIR }}=100-165 \mathrm{~km}$ and $d_{R O D R I D}=110-180 \mathrm{~km}$, assuming typical anisotropy of 3-5\% (Mainprice et al., 2000; Tommasi, 1998) along the vertical direction sampled by XKS waves. Interestingly, the tomographic models of Mazzullo et al. (2017) allows to predict only weak lithospheric anisotropy $\left(\delta t_{\text {pred_lithos }} \leq 0.15 \mathrm{~s}\right)$ that could reflect frozen lithospheric structures as discussed, but stronger asthenospheric anisotropy ( $\delta t_{\text {pred_asthenos }} \geq 0.4 \mathrm{~s}$ ) at depths between $50-200 \mathrm{~km}$. That is also fully consistent with the hot asthenosphere seen by the Rayleigh wave model at these depths. In a cartoon in Fig. 4b, we illustrate our model that shows the hot asthenosphere flowing from beneath the (southern) Mascarene Basin towards the CIR due east, benefiting of the overall lithosphere thinning and potentially feeding La Réunion volcanism along its path.

\subsection{Southwest Indian Ridge}

Along the ultraslow spreading Southwest Indian Ridge (SWIR), where the Somali and Antarctic plates drift apart with rates $<1.5 \mathrm{~cm} / \mathrm{yr}$, we obtained 8 non-null measurements at stations RR36, RR38, and RR44 (Fig. 5a, red box). These measurements average with $\Phi_{\text {SWIR }}=\mathrm{N} 050^{\circ} \mathrm{E}$ (pattern SWIR in Table 1 ) and indicate a good parallelism with the SWIR-axis. This homogeneous anisotropy pattern is also supported by 10 null measurements, as their eventbackazimuths average $B A Z=\mathrm{N} 045^{\circ} \mathrm{E}$. Altogether, our non-null and null measurements are compatible with a one-layered anisotropic model beneath the SWIR.

The SWIR-parallel anisotropic trend, together with the $\Phi$ at off-ridge OBS RR34 trending in the same direction (discussed be- low), is compatible with the plate motion models of GSRM-1, Morgan2007 and NNR-MORVEL56 (Fig. 5a, colored arrows), suggesting that anisotropy may at least partly result from asthenospheric, Somali drag-induced anisotropy. On the other hand, for the Somalia and Antarctica plates, both the difference of absolute plate motions, i.e. the SWIR's movement itself, as well as the relative plate motion as underlined by the numerous fracture-zones, show $\sim \mathrm{N}-\mathrm{S}$ trends and thus likely not cause the ridge-parallel anisotropy signature. For the SWIR's lithospheric anisotropy, we suggest only minor contributions to our observed SWIR-parallel signature, given that the lithosphere-asthenosphere boundary (LAB) deepens maximum $\sim 30 \mathrm{~km}$ along the ridge (Schlindwein and Schmid, 2016). Consistent with this expectation, our tomography-derived XKS predictions show only small delay times in the lithosphere ( $\delta t_{\text {pred_lithos }} \leq 0.1 \mathrm{~s}$ ), but larger ones in the asthenosphere $\left(\delta t_{\text {pred_asthenos }}=1.4 \mathrm{~s}, 0.8 \mathrm{~s}\right.$, and $0.5 \mathrm{~s}$ at RR36, RR38, and RR44). For lithosphere and asthenosphere combined, the tomography-predicted $\Phi$ reproduce our observed $\Phi$ fairly well at RR38 $\left(\Delta \Phi_{\text {pred-meas }}=24^{\circ}\right)$, perfectly at RR44 $\left(\Delta \Phi_{\text {pred-meas }}=1^{\circ}\right)$, and less well at RR36 $\left(\Delta \Phi_{\text {pred-meas }}=42^{\circ}\right)$. This suggests that most of the SWIR's anisotropy is indeed contained within the asthenosphere but only partly caused by (absolute) plate motions. With a measured delay time of $\delta t_{S W I R}=1.0 \mathrm{~s}$, and assuming an anisotropy of $3-5 \%$, we estimate the effective thickness of the anisotropic layer to be $d_{\text {SWIR }}=90-150 \mathrm{~km}$.

We discuss below two different models involving actively versus passively upwelling asthenosphere that may explain our ridgeparallel trends in $\Phi$.

At longitude $40^{\circ} \mathrm{E}$ along the SWIR, $1500 \mathrm{~km}$ southwest of the closest SWIR OBS RR36, slow mantle velocity anomalies have been associated with the Marion and/or Crozet hotspots (Sauter et al., 2009). As proposed by Yamamoto et al. (2007), these mantle upwellings could potentially feed the entire eastern SWIR with asthenospheric material flowing along-axis, channeled between the cold and steeply dipping lithospheric walls. Geochemical analyses (Meyzen et al., 2003), however, show different compositions of mid-ocean ridge basalts to the west and east of the Melville Fracture Zone located at SWIR longitude $61^{\circ} \mathrm{E}$, in the middle of our SWIR transect (Fig. 5a). We hence rule out one common source of material that flows along-axis below the lithosphere feeding the whole SWIR.

Instead, we favor discontinuous, passive asthenospheric upwellings as the dominating cause of anisotropy development. The SWIR is characterized by a succession of magmatic and amagmatic spreading sections. The LAB at ultraslow spreading ridges undulates along-axis (e.g., Schlindwein and Schmid, 2016), and rapidly thickens off-axis due to reduced heat flow and spreading rate. The resulting cold and steep lithospheric walls may channel asthenospheric material that rises from one or more discrete, point-like sources, and guide it along-axis. In places where the LAB shallows, localized melting may generate patchy oceanic crust (Cannat et al., 1999). Lithospheric contributions to ridge-parallel $\Phi$ may be due to the mantle fabrics' lattice preferred orientation (LPO) generated during accretion of lithosphere to the spreading plates. Along-axis, horizontal melt migration within the SWIR's crust and lithosphere (Schmid et al., 2017) could also favorably contribute to the ridgeparallel $\Phi$ (Kendall et al., 2006). We illustrate our model for the SWIR upper mantle with Fig. 5b.

Given our proposed model, along-axis LPO is expected to be frozen into the lithosphere and could be retrieved far off the ridge-axis. Our OBS line RR31 to RR35 could pick up on this structure (Fig. 5a, Box A). Among these stations only RR34 on seafloor aged $\sim 50$ Ma provided non-null splitting measurements. These two measurements average $\Phi_{R R 34}=\mathrm{N} 059^{\circ} \mathrm{E}$ and trend parallel to the overall SWIR-axis (N060 $\left.{ }^{\circ} \mathrm{E}\right)$. We hence propose that RR34's observed anisotropy may represent frozen lithospheric structures 


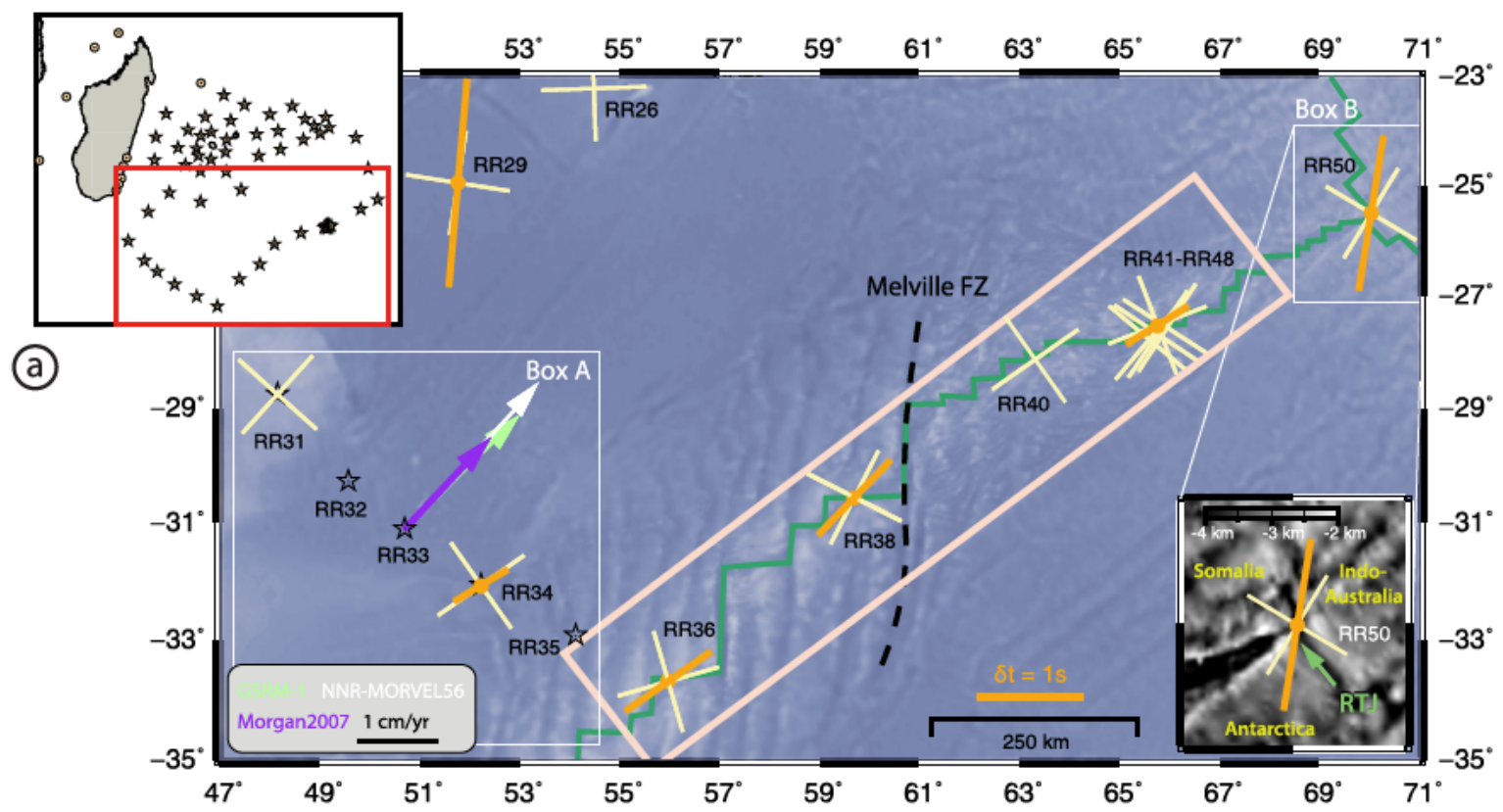

(b)

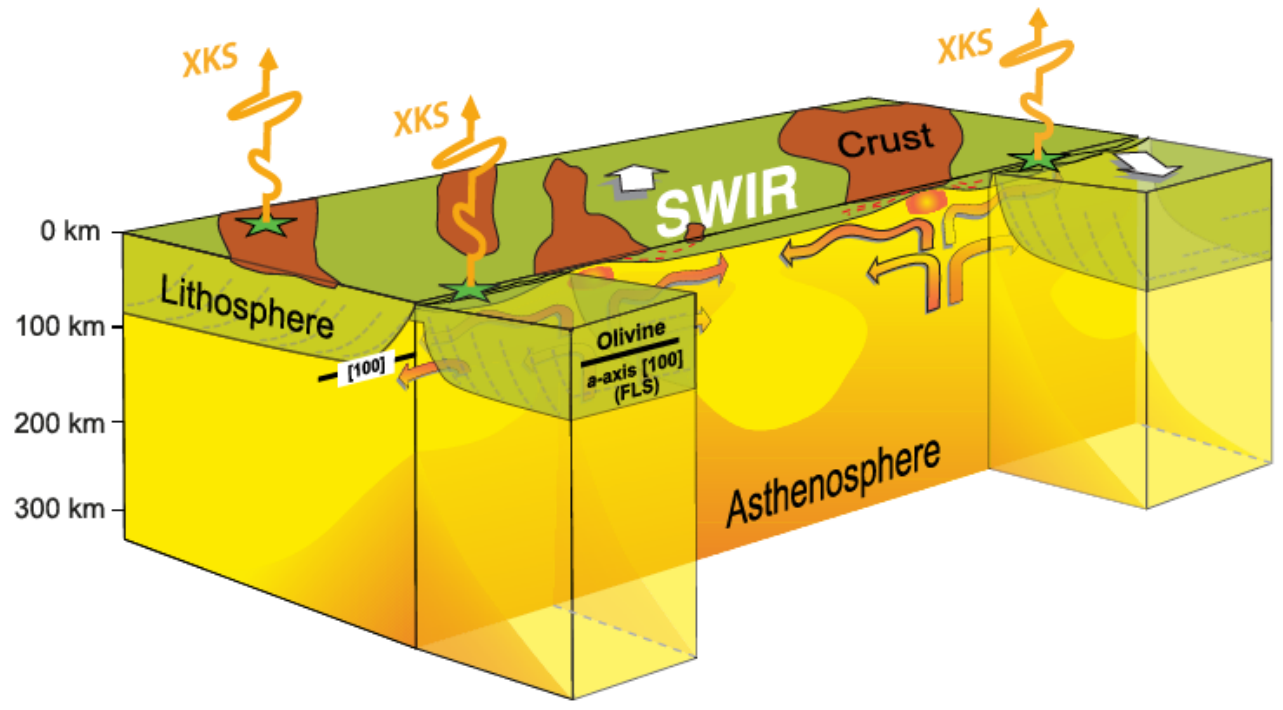

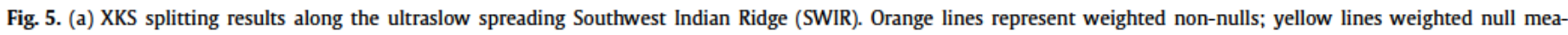

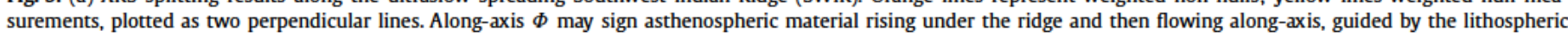

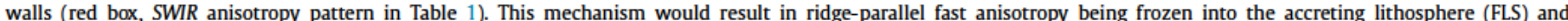

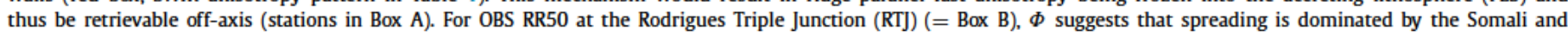
Indo-Australian plates; (b) Cartoon illustrating our SWIR upper mantle model.

acquired $50 \mathrm{Ma}$ ago along the SWIR, with a potential minor contribution due to the drag of the slowly moving Somali plate $(<2.6 \mathrm{~cm} / \mathrm{yr})$.

At the eastern terminus of the SWIR, OBS RR50 was deployed on the Rodrigues Triple Junction (RTJ) where SWIR, CIR and SEIR (Southeast Indian Ridge) meet. At this station, we obtained one non-null measurement trending $\Phi_{R R 50}=\mathrm{N}_{009^{\circ}} \mathrm{E}$ and thus parallel to the strike of the rift valley extending $\sim 40 \mathrm{~km}$ north from the RTJ, separating the Somali and Indo-Australian plates (Fig. 5a, Box B). Although detailed conclusions from a single splitting are not warranted, it may suggest a similar situation as for the SWIR; a predominantly ridge-parallel asthenospheric flow with an estimated effective thickness of $d_{R R 50}=135-220 \mathrm{~km}\left(\delta t_{R R 50}=1.5 \mathrm{~s}\right.$, assumed anisotropy of 3-5\%). This would indicate that upper mantle structure near the RTJ is dominated by the spreading between the Somali and Indo-Australian plates.

\subsection{Mozambique Channel}

In the Mozambique Channel, the measured splitting parameters average $\Phi_{\mathrm{MOZCHA}}=\mathrm{N} 070^{\circ} \mathrm{E}$ and $\delta t_{\mathrm{MOZCHA}}=1.2 \mathrm{~s}$ (Fig. 6a-d; pattern MOZCHA in Table 1). XKS predictions from Rayleigh wave tomography (Mazzullo et al., 2017) reproduce these observations fairly well, but with smaller split times $\left(\Phi_{\text {pred_MOzСHA }}=\mathrm{N} 060^{\circ} \mathrm{E}\right.$, $\delta t_{\text {pred_MоzснA }}=0.6 \mathrm{~s}$ ). The Rayleigh wave tomography further indicates that anisotropy in the Mozambique Channel is mostly located within the first $100-150 \mathrm{~km}$ beneath the surface, coinciding with the lithospheric thicknesses of the LITHO1.0 model (Pasyanos et al., 2014) and suggesting dominant lithospheric anisotropy in the Mozambique Channel. At station MAYO (Mayotte Island) in the Comoros archipelago, we obtained 25 non-null XKS splittings, a much larger number than for the other stations EURO (4), JNOV (2), and GLOR (1), but with some complexity. We observe an apparent rotation of MAYO's $\Phi$ from NE-SW to E-W, depending on 


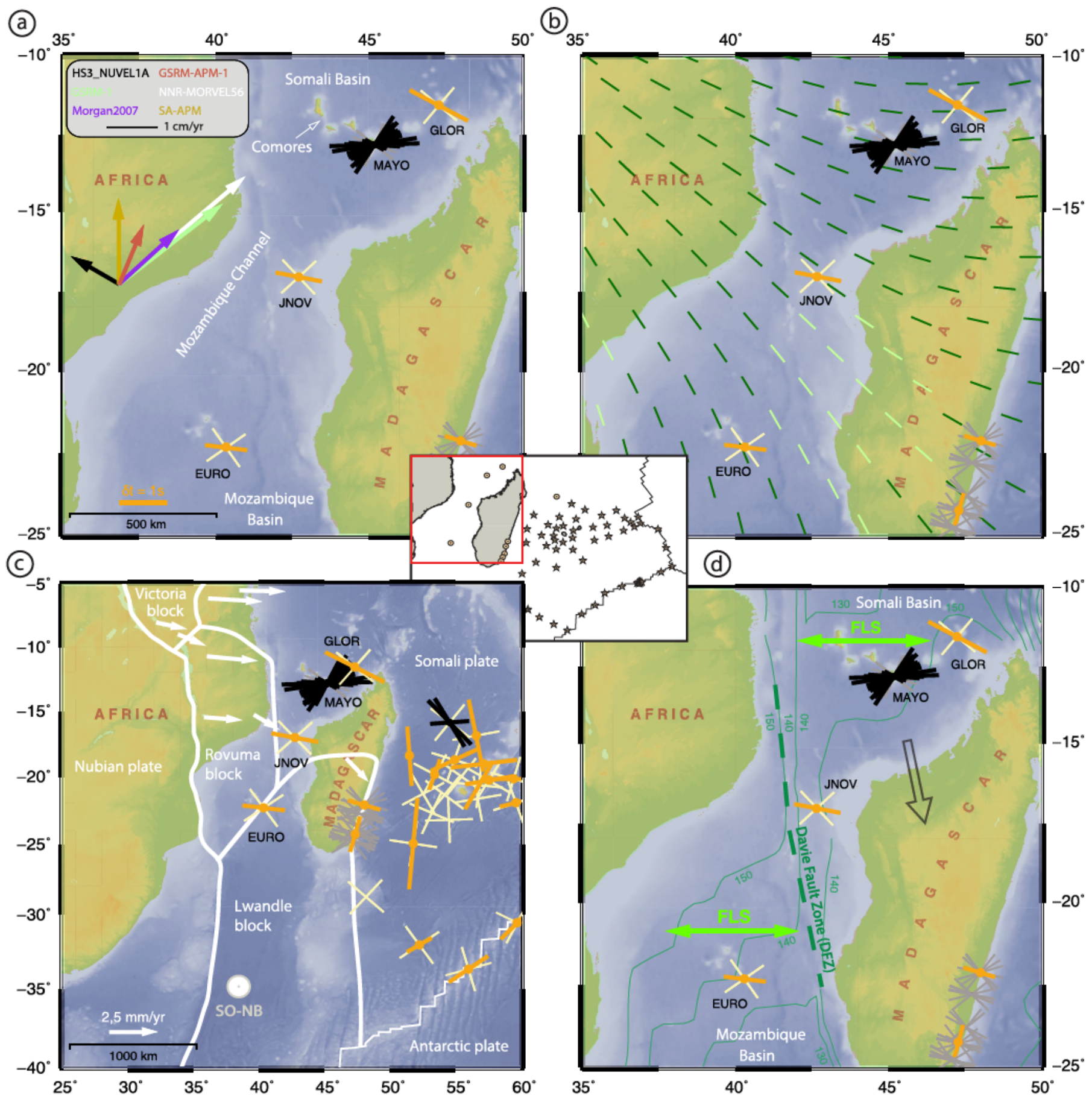

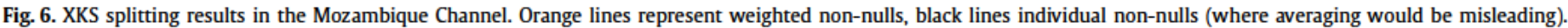

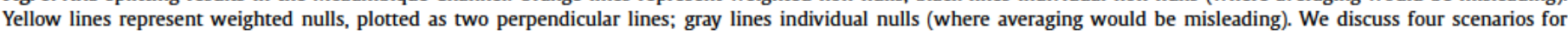

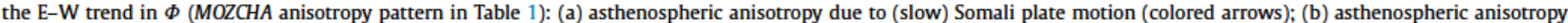

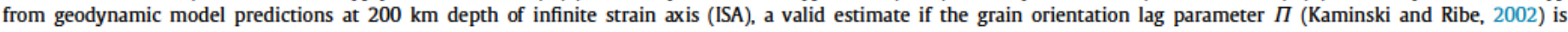

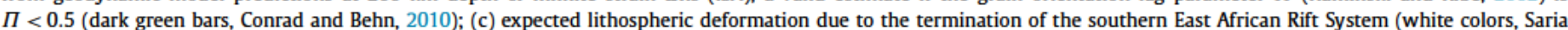

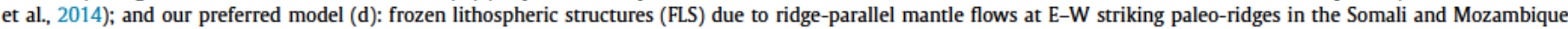

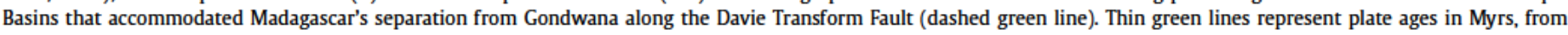
Müller et al. (2008).

the event-backazimuths. Such pattern could indicate upper mantle heterogeneities or a sub-station anisotropy within multiple layers. Following the diagnosis of Silver and Savage (1994) for the simple case of two anisotropic layers, backazimuthal variations in $\Phi$ and $\delta t$ should exhibit a $\pi / 2$-periodicity, which is not the case (supplement Fig. S3), suggesting the observed anisotropy variation beneath MAYO results likely from upper mantle heterogeneities.
We evaluate four scenarios that may explain our observations in the Mozambique Channel. First, the E-W trending $\Phi$ could reflect a common source of asthenospheric anisotropy induced by the Somali plate drag. None of the plate motion models we tested (Fig. 6a, colored arrows) produce compelling fits. Somali plate motion may therefore not be the dominant cause of anisotropy. 
Second, anisotropy may result from large-scale interactions between deep mantle convection and tectonic plates. The mantle flow model proposed by Conrad and Behn (2010) uses plate motions and mantle density heterogeneities to predict asthenospheric anisotropy (Fig. 6b, green bars). These predictions match our E-W observations fairly well at MAYO, but less well at stations GLOR, JNOV and EURO, suggesting that additional and/or different geodynamic processes influence the Mozambique Channel.

Third, anisotropy may result from present-day tectonic processes associated with the East African Rift System. On its southern termination, the mode of lithospheric deformation is diffuse (Kusky et al., 2010) and/or localized along micro-plate boundaries (Stamps et al., 2015), with details still debated. In this tectonic frame (Fig. $6 \mathrm{c}$ ), large-scale extension is expected to trend $\sim \mathrm{E}-\mathrm{W}$, parallel to (most of) our observations. However, one would expect low strain rates and therefore smaller delay times than we observe $\left(\delta t_{M O Z C H A}=1.2 \mathrm{~s}\right)$, suggesting that this process is not dominant either.

Fourth, the E-W trending anisotropy may reside within the oceanic lithosphere as result of Madagascar's paleo-motion in SSE direction, as it detached from Gondwana 170-120 Ma ago (Fig. 6d). This motion occurred along the Davie Fault Zone (DFZ) acting as a transform fault that delineated the opening of the Somali Basin on its northeastern side and the Mozambique Basin on its southwestern side. For these basins, magnetic anomalies (König and Jokat, 2010) and plate reconstructions (Phethean et al., 2016) indicate paleo-ridges trending $\sim \mathrm{E}-\mathrm{W}$ to both sides of the DFZ, with full spreading rates of $\sim 3 \mathrm{~cm} / \mathrm{yr}$, i.e., slow spreading. Assuming ridgeparallel mantle flow at slow spreading ridges, as proposed for the (ultra)slow spreading SWIR (Section 4.4), E-W trending $\Phi$ in the Mozambique Channel could likewise reflect frozen lithospheric structure, oriented parallel to the E-W trending paleo-ridges. For station MAYO, NE-SW trending faults at crustal depths (e.g., Audru et al., 2006) are parallel to part of our observations and could participate to the complex anisotropy at this station. For the entire volcanic alignment of the Comoros archipelago, it is further likely that upper mantle structure has been locally perturbed by the volcanism that started 10-20 Ma ago and which is still active in the Grande Comore (Karthala volcano) and very recent in Mayotte (Michon, 2016).

In summary, from measured and tomography-predicted XKS splitting parameters, we propose the dominant part of E-W trending anisotropy in the Mozambique Channel is located within the lithosphere. We interpret it mainly due to frozen lithospheric structures whose fast split directions trend parallel to the slow spreading paleo-ridges that governed Madagascar's separation from Gondwana (Fig. 6d, scenario 4). Local complexities beneath Mayotte may result from lithospheric local deformation, together with the recent volcanism that created the island. The diffuse termination of the East African Rift System may minorly contribute to the splitting observations (Fig. 6c, scenario 3 ).

\subsection{Madagascar}

We obtained only two non-null measurements on our five RHUM-RUM seismometers in the southeast of Madagascar (Fig. 7; Table 1), an area characterized by past volcanism. At RUM4 we find $\Phi_{\text {RUM4 }}=\mathrm{N} 015^{\circ} \mathrm{E}$, and at RUM2 located $250 \mathrm{~km}$ north of RUM4, $\Phi_{\text {RUM } 2}=\mathrm{N} 107^{\circ} \mathrm{E}$. At all five stations (RUM1-RUM5), the eventbackazimuths of 41 null measurements show no preferred direction (Fig. 7), indicating rather complex structure beneath Madagascar. In the south-eastern part of Madagascar, most of our stations are installed on the continental margin, on volcanic structures dating from the Madagascar-India breakup. It is likely that the complex anisotropy or apparent absence of anisotropy may reflect the complex history suffered by the lithosphere during the Mascarene

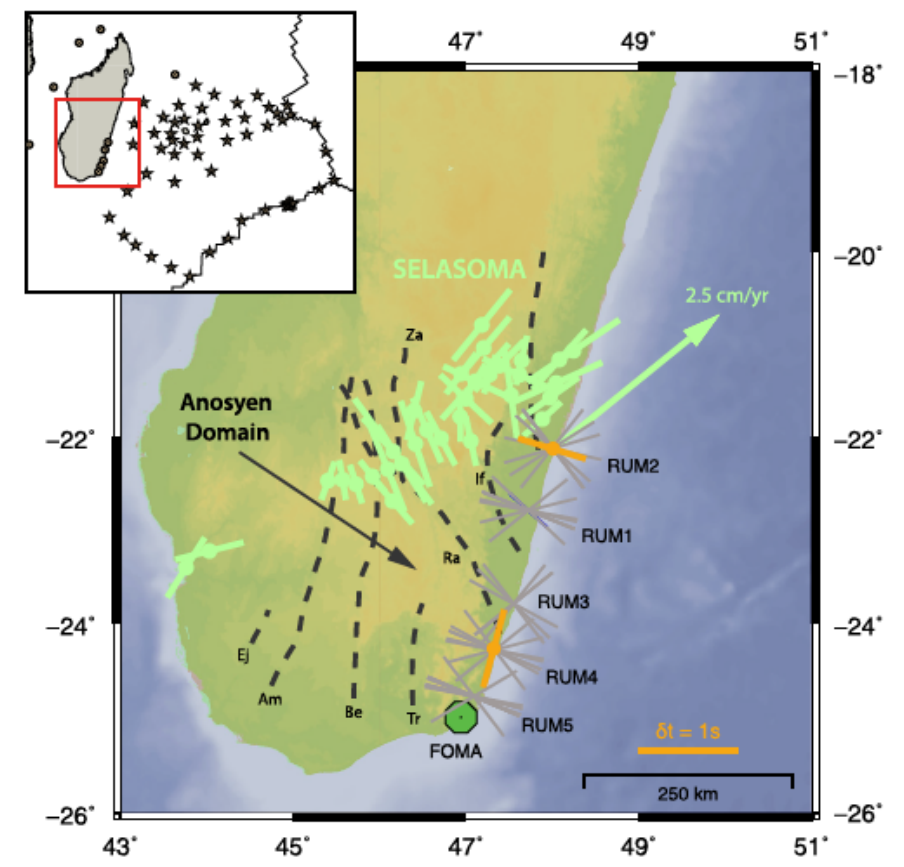

Fig. 7. XKS splitting results on Madagascar. Orange lines represent weighted nonnulls. Gray lines represent individual nulls (where averaging would be misleading) Green lines represent averaged non-nulls obtained by the SELASOMA project (Reiss et al., 2016). Black dashed lines show shear zones after Reiss et al. (2016), originally from Martelat et al. (2000): Ej = Ejeda, $\mathrm{Am}=$ Ampanihy, $\mathrm{Be}=$ Beraketa, $\mathrm{Ta}=$ Tranomaro, $\mathrm{Ra}=$ Ranotsara, If = Ifanadiana, $\mathrm{Za}=$ Zazafotsy. At RUM4, N-S trending $\Phi$ are parallel to $\mathrm{N}-\mathrm{S}$ trending lithospheric shear zones in the Anosyen Domain. At RUM2, E-W trending $\Phi$ does not match nearby SELASOMA measurements which in that area were mainly attributed to Somali plate motion (green arrow $=$ motion vector of GSRM-1 model of Kreemer et al., 2003).

Basin opening, involving rifting, tearing, and volcanism, but also the interaction with the underlying asthenosphere.

At station RUM4, N-S oriented lithospheric shear zones may explain N-S trending $\Phi$. At the GEOSCOPE station FOMA located close to RUM4, the lithospheric thickness is up to $90 \mathrm{~km}$ (Rindraharisaona et al., 2013), suggesting that $\delta t_{R U M 4}=0.8$ s could be indeed accommodated within the lithosphere.

For RUM2, one could hypothesize that our E-W observation is related to shear wave velocity anomalies (Pratt et al., 2017) that may indicate (horizontal) movement of sub-lithospheric material driven by a regionally thinned lithosphere. However, nearby SKS measurements of the SELASOMA project (Reiss et al., 2016) show SW-NE trending $\Phi$ that do not agree with our observation (Fig. 7, green bars), except if one involves strong, short-scale lithospheric structure variations. In this area, the authors attribute their $\Phi$ mainly to asthenospheric anisotropy caused by Somali plate motion (Fig. 7, green arrow). Our tomography-derived XKS predictions likewise suggest SW-NE trending $\Phi$ for the upper mantle beneath Madagascar, which agrees with the measurements of Reiss et al. (2016), but not with ours. We therefore suggest that our two nonnull measurements on Madagascar result from a combination of lithospheric and asthenospheric anisotropy contributions, however, contributions from the $D^{\prime \prime}$ cannot be excluded.

\section{Discussion}

Generally, for the Western Indian Ocean our XKS splitting observations largely coincide with the azimuthal anisotropies determined by global waveform studies (e.g., Debayle et al., 2016; Schaeffer et al., 2016) and mantle flow computations (e.g., Becker et al., 2008; Conrad and Behn, 2010 - the latter with constraints on the Mozambique Channel for example). 


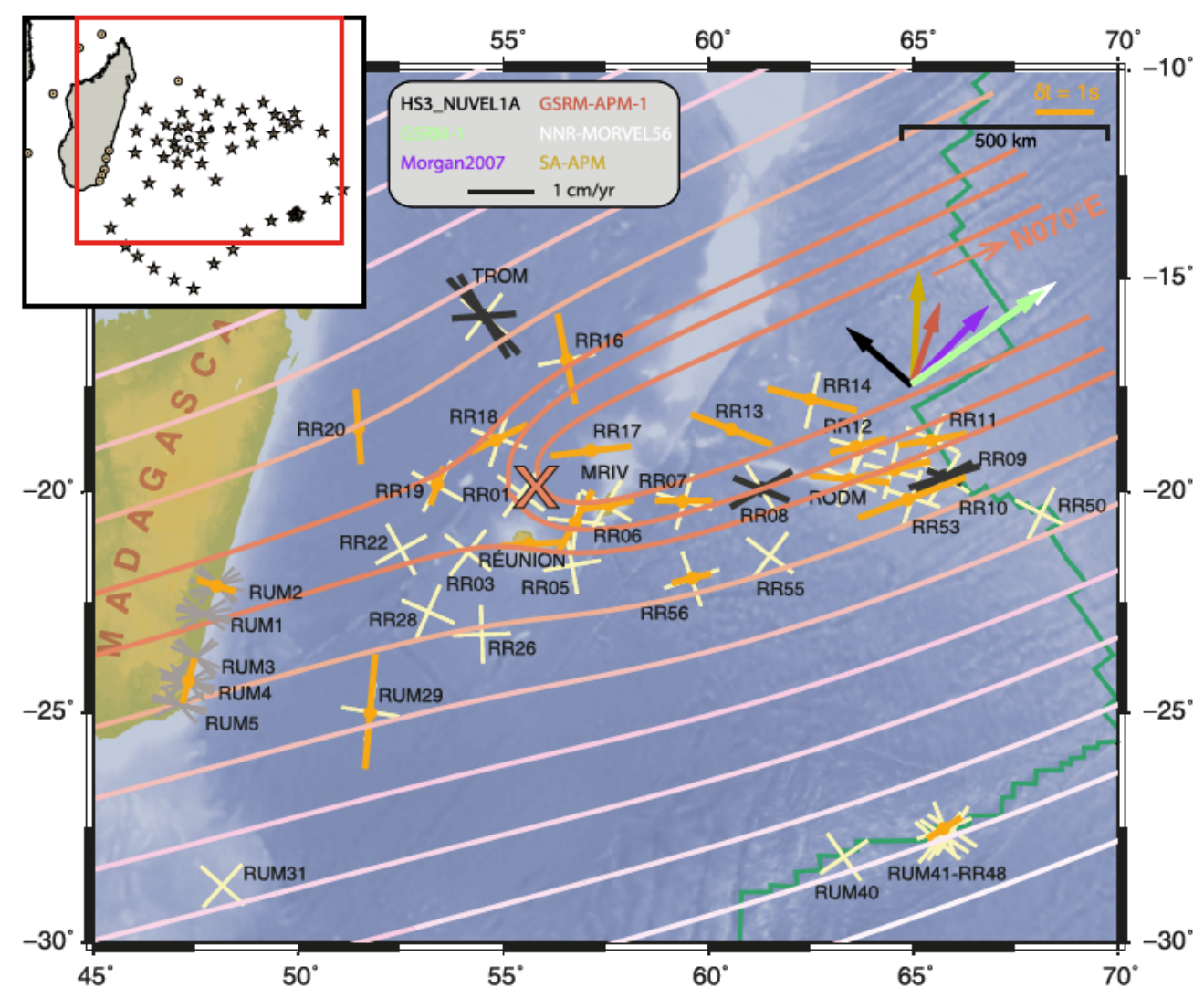

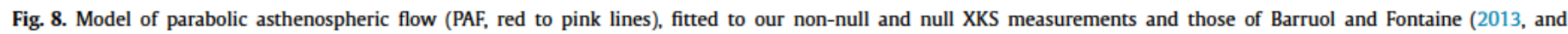

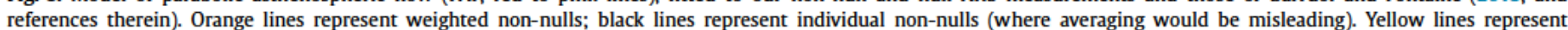

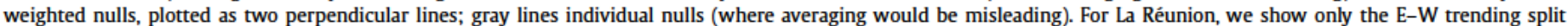

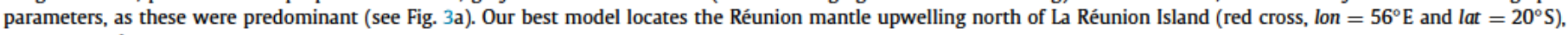

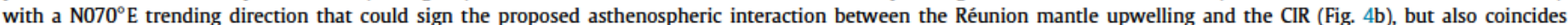
with some Somali plate motion vectors (colored arrows).

In Table 2, we classified our interpretations of our XKS splitting measurements performed on active or fossil mid-ocean ridges in the Western Indian Ocean and around La Réunion hotspot. Table 2 also provides a compilation of previously published shear wave splitting studies in similar geodynamic contexts.

From our XKS measurements we note that the plate drag of the slow Somali plate motion $(<2.6 \mathrm{~cm} / \mathrm{yr})$ is likely too weak to generate dominant anisotropic fabric. This observation is unexpected but not surprising, as faster moving plates allow stronger development of differential shear at their base (Tommasi, 1998), thereby creating stronger patterns of seismic anisotropy. The fastmoving Pacific plate $(>10 \mathrm{~cm} / \mathrm{yr})$ is one such example (e.g., Wolfe and Solomon, 1998; Walker et al., 2001; Harmon et al., 2004; Fontaine et al., 2007; Barruol et al., 2009; Martin-Short et al., 2015; Table 2).

Along mid-ocean ridges, fast split directions $(\Phi)$ are generally attributed to asthenospheric mantle flow (AF) related to the ridges' spreading processes and to absolute/relative plate motions (PM). The synopsis of this and previous studies shows, $\Phi$ orient either ridge-parallel or ridge-normal (Table 2). We propose that this process is a function of the ridges' (full) spreading rate: $\Phi$ orients ridge-normal at fast to intermediate spreading ridges, such as the Central Indian Ridge (Section 4.3), but orients ridge-parallel at slower spreading ridges, such as the Southwest Indian Ridge (Section 4.4) and the paleo-ridges in the Mozambique Channel (Section 4.5). Spreading rate may therefore control the direction of underlying mantle flow at mid-ocean ridges and consequently the frozen lithospheric structure (FLS) accompanying plate constructions at these places. An exception to this may be the intermediate spreading Juan de Fuca Ridge that exhibits ridge-parallel $\Phi$, next to the diffuse spreading Gorda Ridge dominated by ridge-normal $\Phi$ (Bodmer et al., 2015; Martin-Short et al., 2015; Table 2). However, both these ridges are located in the fore-arc of the Cascadia subduction zone that may affect their underlying upper mantle flows.

Interestingly, the eastern North American Margin is a region where XKS splitting on old seafloor shows $\Phi$ oriented parallel to the present and former Mid-Atlantic Ridge (Lynner and Bodmer, 2017). Considering that the Central Atlantic spread very slowly during its early rifting phases (e.g., Müller et al., 2008), we hypothesize that the observed $\Phi$ near the U.S. eastern seaboard could reflect ridge-parallel FLS analogous to those presently generated by the ultraslow spreading SWIR - whereas Lynner and Bodmer (2017) assumed ridge-normal FLS by default and instead proposed a present-day, continental margin-parallel asthenospheric mantle flow as dominant cause.

Around hotspots, seismic anisotropy is often interpreted as a combination of FLS and sub-lithospheric mantle shearing associated with PM (Table 2). Models of parabolic asthenospheric flow (PAF) have often been hypothesized for plumes rising and spreading beneath moving plates, and tested against the observed splitting parameters. From XKS splitting on La Réunion and Mauritius, Barruol and Fontaine (2013) tested such hypotheses and found the best model was a point-like source of upwelling located North of La Réunion (lon $=56^{\circ} \mathrm{E}$, lat $=20^{\circ} \mathrm{S}$ ), with an absolute Somali plate motion trending $\mathrm{N} 030^{\circ} \mathrm{E}$. In the present study, also including their non-null/null splitting measurements and using the same modeling approach (Walker et al., 2001), we tested similar mantle upwelling locations and characteristics (N052 $\leq$ lon $\leq \mathrm{N} 059^{\circ} \mathrm{E}$, $23 \leq$ lat $\leq 17^{\circ} \mathrm{S}, 0.002 \leq$ AVratio $\leq 0.012$, N020 $\leq A P M \leq \mathrm{N} 090^{\circ} \mathrm{E}$ ). As seen in Fig. 8, our best model locates the upwelling source at 
the same location as Barruol and Fontaine (2013), with a rather active upwelling (AVratio $=0.012$ ), and with an asthenospheric spreading $\mathrm{N} 070^{\circ} \mathrm{E}$ and thus close to our proposed active asthenospheric mantle flow striking $N 079^{\circ} \mathrm{E}$ (pattern RÉU-CIR in Fig. 4 and Table 1). The new trend of this asthenospheric spreading is obviously controlled by our new XKS splitting records and may sign the interaction between the Réunion mantle upwelling and the $\mathrm{CIR}$, rather than the drag exerted by the slow Somali plate motion (although this cannot be excluded as the plate motion models of GSRM-1, Morgan2007, and NNR-MORVEL56 show good fits, Fig. 8). Our model does well at explaining the rotating $\Phi$ around La Réunion, but not the N-S trending $\Phi$ in the Mascarene Basin that may reflect fossil lithosphere structure. Such modeling has, however, strong limitations because the actual source of mantle upwelling is probably neither nearly point-like, as suggested by surface wave tomography (Mazzullo et al., 2017), nor vertical.

\section{Conclusions}

As part of the RHUM-RUM project that investigates wholemantle structure beneath the Réunion hotspot in the Western Indian Ocean, we presented XKS splitting measurements for 20 terrestrial and 40 ocean-bottom seismometers (Fig. 1; Table 1), installed temporarily between 2011-2016 (land stations) and 2012-2013 (seafloor stations). We compared measured XKS splitting parameters with predicted XKS splitting parameters computed from a regional, azimuthally anisotropic Rayleigh wave tomography (Mazzullo et al., 2017). Our first order conclusions are as follows:

Asthenospheric anisotropy caused by present-day plate motion appears to be minor in the entire Western Indian Ocean. We attribute this to the slow motion of the Somali plate $(<2.6 \mathrm{~cm} / \mathrm{yr})$, with accordingly weak shearing at its base. This observation contrasts with XKS studies of faster moving plates, such as the Pacific plate (velocity $>10 \mathrm{~cm} / \mathrm{yr}$ ), where seismic anisotropy is dominated by sub-lithospheric mantle shearing.

Seismic anisotropy on La Réunion and in the Mascarene Basin is complex, likely due to a superposition of two contributions of similar magnitudes: (i) structure frozen into the lithosphere of the Somali plate during its formation (opening of the Mascarene Basin and paleo-spreading of the Central Indian Ridge, Fig. 3), and (ii) the current or recent flow of asthenosphere, from beneath La Réunion towards the CIR, for which we present strong seismological evidence (Fig. 4). Supporting the original hypothesis of Morgan (1978), our observations indicate that this asthenospheric flow is likely fed by the Réunion mantle upwelling (either a deep plume or mantle rising from beneath the Mascarene Basin - a question beyond the scope of this study) and has always remained in correspondence with the nearest CIR segment, currently at $1000 \mathrm{~km}$ distance. For this setting, we find a model of parabolic asthenospheric flow that fits our observations, keeping in mind that a vertical, point-like upwelling beneath La Réunion is likely not reflecting the complex nature such upwellings may inherit (i.e., inclined and broad-scale, as opposed to vertical and point-like).

At the ultraslow spreading Southwest Indian Ridge (SWIR), we interpret ridge-parallel $\Phi$ as along-axis flow of asthenospheric mantle rising from discrete mantle upwellings. This material may subsequently be channeled by the cold and steep lithospheric walls and guided along-axis by the undulating lithosphereasthenosphere boundary. During plate accretion, such ridge-parallel fast split directions may have become frozen into the lithosphere and would consequently be observed far off the SWIR-axis (Fig. 5).

In the Mozambique Channel, E-W trending $\Phi$ may mostly represent frozen lithospheric anisotropy acquired at the slowspreading, E-W trending paleo-ridges that were active during Madagascar's escape from Gondwana 170-120 Ma ago (Fig. 6d).
For mid-ocean ridges, we propose that $\Phi$ - and therefore mantle flows - are controlled by the ridge spreading rate; ridge-normal $\Phi$ are observed at fast and intermediate spreading ridges (e.g., Central Indian Ridge and East Pacific Rise), whereas ridge-parallel $\Phi$ are observed at slower spreading ridges (e.g., Southwest Indian Ridge and Mid-Atlantic Ridge) and also frozen into seafloor that originally formed at slow-spreading ridges (e.g., Mozambique Channel and NW Atlantic).

\section{Acknowledgements}

The presented XKS splitting measurements can be found in the on-line supplements and in our splitting data-base (http://splitting. gm.univ-montp2.fr/DB/public/searchdatabase.html), which is also mirrored at IRIS (Incorporated Research Institutions for Seismology, https://ds.iris.edu/spud/swsmeasurement). The RHUM-RUM project (http://www.rhum-rum.net) was funded by ANR (Agence Nationale de la Recherche) in France (project ANR-11-BS56-0013), and by DFG (Deutsche Forschungsgemeinschaft) in Germany (grants SI1538/2-1 and SI1538/4-1). Additional support was provided by CNRS (Centre National de la Recherche Scientifique, France), TAAF (Terres Australes et Antarctiques Françaises, France), IPEV (Institut Polaire Français Paul Emile Victor, France), and AWI (AlfredWegener-Institut, Germany, grant SCHL853/3-1). K.S. received funding from the People Programme (Marie Curie Actions) of the European Union's Seventh Framework Programme FP7/2007-2013/ under REA grant agreement no. PCIG14-GA-2013-631104 RHUMRUM. We thank DEPAS (Deutsche Geräte-Pool für Amphibische Seismologie, Germany), GEOMAR (GEOMAR Helmholtz-Zentrum für Ozeanforschung Kiel, Germany) and INSU-IPGP (Institut National des Sciences de l'Univers - Institut de Physique du Globe de Paris, France) for providing 57 broadband and wideband oceanbottom seismometers (44 DEPAS, 4 GEOMAR, 9 INSU-IPGP). We thank AWI, RESIF-SISMOB (Réseau Sismologique and Géodésique Français - parc d'instruments sismologiques mobiles, France), and the Universities of Bonn, Münster, and La Réunion for providing 20 broadband terrestrial seismometers (5 AWI, 5 RESIF-SISMOB, 4 Bonn, 4 Münster, 2 La Réunion). The RHUM-RUM data set (https://doi.org/10.15778/RESIF.YV2011) is assigned to the FDSN network code YV and accessible via the French data-center RESIF (http://seismology.resif.fr). We thank cruise participants and crew members on the French R/V Marion Dufresne (deployment cruise MD192; Barruol, 2014) and on the German R/V Meteor (recovery cruise M101; Sigloch, 2013). We used the open-source toolboxes GMT v.5.3 (Wessel et al., 2013), Python v.2.7 (Rossum, 1995), and ObsPy v.1.0 (Beyreuther et al., 2010). We thank Mathilde Cannat for insightful discussions and the reviewers for their highly valuable comments. This is IPGP contribution 3882.

\section{Appendix A. Supplementary material}

Supplementary material related to this article can be found online at https://doi.org/10.1016/j.epsl.2018.06.033.

\section{References}

Alsina, D., Snieder, R., 1994. Small-scale sublithospheric continental mantle deformation: constraints from SKS splitting observations. Geophys. J. Int. 123, 431-448. https://doi.org/10.1111/j.1365-246X.1995.tb06864.x.

Amante, C., Eakins, B.W., 2009. NOAA Technical Memorandum NESDIS NGDC-24. National Geophysical Data Center, NOAA.

Argus, D.F., Gordon, R.G., DeMets, C., 2011. Geologically current motion of 56 plates relative to the no-net-rotation reference frame. Geochem. Geophys. Geosyst. 12 https://doi.org/10.1029/2011GC003751.

Audru, J.-C., Guennoc, P., Thinon, I., Abellard, O., 2006. Bathymay: la structure sousmarine de Mayotte révélée par l'imagerie multifaisceaux. C. R. Géosci. 338, 1240-1249. https://doi.org/10.1016/j.crte.2006.07.010.

Barruol, G., 2014. RHUM-RUM Marion Dufresne MD192 cruise report Sept.-Oct 2012. https://doi.org/10.13140/2.1.2492.0640. 
Barruol, G., Fontaine, F.R., 2013. Mantle flow beneath La Réunion hotspot track from SKS splitting. Earth Planet. Sci. Lett. 362, 108-121. https://doi.org/10.1016/j.epsl. 2012.11.017.

Barruol, G., Sigloch, K., 2013. Investigating La Réunion hot spot from crust to core. Eos 94, 205-207. https://doi.org/10.1002/2013EO230002.

Barruol, G., Suetsugu, D., Shiobara, H., Sugioka, H., Tanaka, S., Bokelmann, G.H.R., Fontaine, F.R., Reymond, D., 2009. Mapping upper mantle flow beneath French Polynesia from broadband ocean bottom seismic observations. Geophys. Res. Lett. 36. https://doi.org/10.1029/2009GL038139.

Becker, T.W., Kustowski, B., Ekström, G., 2008. Radial seismic anisotropy as a constraint for upper mantle rheology. Earth Planet. Sci. Lett. 267, 213-227. https: doi.org/10.1016/j.epsl.2007.11.038.

Becker, T.W., Schaeffer, A.J., Lebedev, S., Conrad, C.P., 2015. Toward a generalized plate motion reference frame. Geophys. Res. Lett. 42, 3188-3196. https://doi. org/10.1002/2015GL063695.

Beyreuther, M., Barsch, R., Krischer, L., Megies, T., Behr, Y., Wassermann, J., 2010. ObsPy: a Python toolbox for seismology. Seismol. Res. Lett. 81, 530-533. https:// doi.org/10.1785/gssrl.81.3.530.

Bird, P., 2003. An updated digital model of plate boundaries. Geochem. Geophys. Geosyst. 4. https://doi.org/10.1029/2001GC000252.

Bissessur, P.D., 2011. Structure, Age and Evolution of the Mascarene Basin, Western Indian Ocean. Doctorate Thesis. IPGP, Paris.

Bjarnason, I.T., Silver, P.G., Rümpker, G., Solomon, S.C., 2002. Shear wave splitting across the Iceland hot spot: results from the ICEMELT experiment. J. Geophys. Res. 107. https://doi.org/10.1029/2001JB000916. ESE 23-1-ESE 23-12.

Bodmer, M., Toomey, D.R., Hooft, E.E., Nábělek, J., Braunmiller, J., 2015. Seismic anisotropy beneath the Juan de Fuca plate system: evidence for heterogeneous mantle flow. Geology 43 (12), 1095-1098. https://doi.org/10.1130/G37181.1.

Brenguier, F., Kowalski, P., Staudacher, T., Ferrazzini, V., Lauret, F., Boissier, P., Catherine, P., Lemarchand, A., Pequegnat, C., Meric, O., Pardo, C., Peltier, A., Tait, S. Shapiro, N.M., Campillo, M., Di Muro, A., 2012. First results from the UnderVolc High Resolution Seismic and GPS network deployed on Piton de la Fournaise volcano. Seismol. Res. Lett. 83, 97-102. https://doi.org/10.1785/gssrl.83.1.97.

Burgos, G., Montagner, J.-P., Beucler, E., Capdeville, Y., Mocquet, A., Drilleau, M., 2014. Oceanic lithosphere-asthenosphere boundary from surface wave dispersion data. J. Geophys. Res. 119, 1079-1093.

Cannat, M., Rommevaux-Jestin, C., Sauter, D., Deplus, C., Mendel, V., 1999. Formation of the axial relief at the very slow spreading Southwest Indian Ridge $\left(49^{\circ}\right.$ to $69^{\circ}$ E). J. Geophys. Res. 104, 22825-22843

Collins, J.A., Wolfe, C.J., Laske, G., 2012. Shear wave splitting at the Hawaiian hot spot from the PLUME land and ocean bottom seismometer deployments. Geochem. Geophys. Geosyst. 13. https://doi.org/10.1029/2011GC003881.

Conrad, C.P., Behn, M.D., 2010. Constraints on lithosphere net rotation and asthenospheric viscosity from global mantle flow models and seismic anisotropy Geochem. Geophys. Geosyst. 11. https://doi.org/10.1029/2009GC002970.

Courtillot, V., Besse, J., Vandamme, D., Montigny, R., Jeager, J.-J., Capetta, H., 1986. Deccan flood basalts at the Cretaceous/Tertiary boundary? Earth Planet. Sci. Lett. 80, 361-374. https://doi.org/10.1016/0012-821X(86)90118-4.

Courtillot, V., Davaille, A., Besse, J., Stock, J., 2003. Three distinct types of hotspots in the Earth's mantle. Earth Planet. Sci. Lett. 2005, 295-308.

Debayle, E., Dubuffet, F., Durand, S., 2016. An automatically updated S-wave model of the upper mantle and the depth extent of azimuthal anisotropy. Geophys. Res. Lett. 43, 674-682. https://doi.org/10.1002/2015GL067329.

Duncan, R.A., 1990. ${ }^{40} \mathrm{Ar} /{ }^{39} \mathrm{Ar}$ geochronology of basement rocks from the Mascarene Plateau, the Chagos Bank, and the Maldives Ridge. Proc. Ocean Drill. Program Sci. Results 115, 43-51.

Duncan, R.A., Backman, J., Peterson, L.C., et al., 1990. The volcanic record of the Reunion Hotspot. Proc. Ocean Drill. Program Sci. Results 115, 3-10.

Fontaine, F.R., Barruol, G., Tkalčić, H., Wölbern, I., Rümpker, G., Bodin, T., Haugmard, M., 2015. Crustal and uppermost mantle structure variation beneath La Réunion hotspot track. Geophys. J. Int. 203, 107-126. https://doi.org/10.1093/gji/ggv279.

Fontaine, F.R., Barruol, G., Tommasi, A., Bokelmann, G.H.R., 2007. Upper-mantle flow beneath French Polynesia from shear wave splitting. Geophys. J. Int. 170, 1262-1288. https://doi.org/10.1111/j.1365-246X.2007.03475.x.

Fontaine, F.R., Hooft, E.E.E., Burkett, P.G., Toomey, D.R., Solomon, S.C., Silver, P.G., 2005. Shear-wave splitting beneath the Galápagos Archipelago. Geophys. Res. Lett. 32. https://doi.org/10.1029/2005GL024014.

Forte, A.M., Quéré, S., Moucha, R., Simmons, N.A., Grand, S.P., Mitrovica, J.X., Rowley, D.B., 2010. Joint seismic-geodynamic-mineral physical modelling of African geodynamics: a reconciliation of deep-mantle convection with surface geophysical constraints. Earth Planet. Sci. Lett. 295, 329-341. https://doi.org/10.1016/j.epsl. 2010.03.017.

Gripp, A.E., Gordon, R.G., 2002. Young tracks of hotspots and current plate velocities. Geophys. J. Int. 150, 321-361. https://doi.org/10.1046/j.1365-246X.2002.01627.x.

Hall, S.A., Kendall, J.-M., van der Baan, M., 2004. Some comments on the effects of lower-mantle anisotropy on SKS and SKKS phases. Phys. Earth Planet. Inter. 146 469-481. https://doi.org/10.1016/j.pepi.2004.05.002.

Harmon, N., Forsyth, D.W., Fischer, K.M., 2004. Variations in shear-wave splitting in young Pacific seafloor. Geophys. Res. Lett. 31. https://doi.org/10.1029/ 2004GL020495.
Kaminski, E., Ribe, N.M., 2002. Timescales for the evolution of seismic anisotropy in mantle flow. Geochem. Geophys. Geosyst. 3, 1-17. https://doi.org/10.1029/ 2001GC000222.

Kendall, J.-M., Pilidou, S., Keir, D., Bastow, I.D., Stuart, G.W., Ayele, A., 2006. Mantle upwellings, melt migration and the rifting of Africa: insights from seismic anisotropy. Geol. Soc. (Lond.) Spec. Publ. 259, 55-72. https://doi.org/10.1144/ GSL.SP.2006.259.01.06.

Kendall, J.M., Silver, P.G., 1996. Constraints from seismic anisotropy on the nature of the lowermost mantle. Nature 381, 409-412. https://doi.org/10.1038/381409a0.

König, M., Jokat, W., 2010. Advanced insights into magmatism and volcanism of the Mozambique Ridge and Mozambique Basin in the view of new potential field data. Geophys. J. Int. 180, 158-180. https://doi.org/10.1111/j.1365-246X. 2009.04433.x.

Kreemer, C., 2009. Absolute plate motions constrained by shear wave splitting orientations with implications for hot spot motions and mantle flow. J. Geophys. Res. 114. https://doi.org/10.1029/2009JB006416.

Kreemer, C., Holt, W.E., Haines, A.J., 2003. An integrated global model of presentday plate motions and plate boundary deformation. Geophys. J. Int. 154, 8-34. https://doi.org/10.1046/j.1365-246X.2003.01917.x.

Kusky, T.M., Toraman, E., Raharimahefa, T., Rasoazanamparany, C., 2010. Active tectonics of the Alaotra-Ankay Graben System, Madagascar: possible extension of Somalian-African diffusive plate boundary? Gondwana Res. 18, 274-294. https://doi.org/10.1016/j.gr.2010.02.003.

Li, A., Detrick, R.S., 2003. Azimuthal anisotropy and phase velocity beneath Iceland: implication for plume-ridge interaction. Earth Planet. Sci. Lett. 214, 153-165. https://doi.org/10.1016/S0012-821X(03)00382-0.

Long, M.D., 2009. Complex anisotropy in $\mathrm{D}^{\prime \prime}$ beneath the eastern Pacific from SKS-SKKS splitting discrepancies. Earth Planet. Sci. Lett. 283, 181-189. https:// doi.org/10.1016/j.epsl.2009.04.019.

Lynner, C., Bodmer, M., 2017. Mantle flow along the eastern North American margin inferred from shear wave splitting. Geology 45, 867-870. https://doi.org/10. 1130/G38980.1.

Mainprice, D., Barruol, G., Ben-Ismail, W., 2000. The seismic anisotropy of the Earth's mantle: from single crystal to polycrystal. In: Earth's Deep Interior: Mineral Physics and Tomography from the Atomic to the Global Scale. AGU, Washington, DC, pp. 237-264.

Martelat, J.-E., Lardeaux, J.-M., Nicollet, C., Rakotondrazafy, R., 2000. Strain pattern and late Precambrian deformation history in southern Madagascar. Precambrian Res. 102, 1-20. https://doi.org/10.1016/S0301-9268(99)00083-2.

Martin-Short, R., Allen, R.M., Bastow, I.D., Totten, E., Richards, M.A., 2015. Mantle flow geometry from ridge to trench beneath the Gorda-Juan de Fuca plate system. Nat. Geosci. 8, 965-968. https://doi.org/10.1038/ngeo2569.

Mazzullo, A., Stutzmann, E., Montagner, J.-P., Maurya, S., Kiselev, S., Barruol, G., Sigloch, K., 2017. Anisotropic tomography around Réunion Island from Rayleigh waves. J. Geophys. Res. 122. https://doi.org/10.1002/2017JB014354.

Meyzen, C.M., Toplis, M.J., Humler, E., Ludden, J.N., Mével, C., 2003. A discontinuity in mantle composition beneath the southwest Indian ridge. Nature 421, 731 .

Michon, L., 2016. The volcanism of the Comoros archipelago integrated at a regional scale. In: Bachelery, P., Lenat, J.-F., Di Muro, A., Michon, L. (Eds.), Active Volcanoes of the Southwest Indian Ocean. Springer, Berlin, Heidelberg, pp. 333-344.

Michon, L., Saint-Ange, F., Bachelery, P., Villeneuve, N., Staudacher, T., 2007. Role of the structural inheritance of the oceanic lithosphere in the magmato-tectonic evolution of Piton de la Fournaise volcano (La Réunion Island). J. Geophys. Res. 112. https://doi.org/10.1029/2006JB004598.

Montagner, J.-P., Griot-Pommera, D.-A., Lavé, J., 2000. How to relate body wave and surface wave anisotropy? J. Geophys. Res. 105, 19015-19027. https://doi.org/10. 1029/2000JB900015.

Morgan, J.P., Morgan, W.J., Zhang, Y.-S., Smith, W.H.F., 1995. Observation hints for a plume-fed, suboceanic asthenosphere and its role in mantle convection. J. Geophys. Res. 100, 12753-12767.

Morgan, W.J., 1978. Rodriguez, Darwin, Amsterdam, ..., a second type of hotspot island. J. Geophys. Res. 83, 5355-5360.

Morgan, W.J., 1972. Deep mantle convection plumes and plate motions. Am. Assoc. Pet. Geol. Bull. 56, 203-213.

Morgan, W.J., Morgan, J.P., 2007. Plate velocities in the hotspot reference frame. Spec. Pap., Geol. Soc. Am. 430, 65-78. https://doi.org/10.1130/2007.2430(04).

Müller, R.D., Sdrolias, M., Gaina, C., Roest, W.R., 2008. Age, spreading rates, and spreading asymmetry of the world's ocean crust. Geochem. Geophys. Geosyst. 9. https://doi.org/10.1029/2007GC001743.

Nicolas, A., Christensen, N.I., 1987. Formation of anisotropy in upper mantle peridotites - a review. Compos. Struct. Dyn. Lithosphere-Asthenosphere Syst., 111-123. https://doi.org/10.1029/GD016p0111.

Pasyanos, M.E., Masters, T.G., Laske, G., Ma, Z., 2014. LITHO1.0: an updated crust and lithospheric model of the Earth: LITHO1.0. J. Geophys. Res. 119, 2153-2173. https://doi.org/10.1002/2013JB010626.

Phethean, J.J.J., Kalnins, L.M., van Hunen, J., Biffi, P.G., Davies, R.J., McCaffrey, K.J.W., 2016. Madagascar's escape from Africa: a high-resolution plate reconstruction for the Western Somali Basin and implications for supercontinent dispersal. Geochem. Geophys. Geosyst. 17, 5036-5055. https://doi.org/10.1002/ 2016 GC006624. 
Pratt, M.J., Wysession, M.E., Aleqabi, G., Wiens, D.A., Nyblade, A.A., Shore, P., Rambolamanana, G., Andriampenomanana, F., Rakotondraibe, T., Tucker, R.D., Barruol, G., Rindraharisaona, E., 2017. Shear velocity structure of the crust and upper mantle of Madagascar derived from surface wave tomography. Earth Planet. Sci. Lett. 458, 405-417. https://doi.org/10.1016/j.epsl.2016.10.041.

Reiss, M.C., Rümpker, G., Tilmann, F., Yuan, X., Giese, J., Rindraharisaona, E.J., 2016. Seismic anisotropy of the lithosphere and asthenosphere beneath southern Madagascar from teleseismic shear wave splitting analysis and waveform modeling. J. Geophys. Res. 121, 6627-6643. https://doi.org/10.1002/2016JB013020.

Richards, M.A., Alvarez, W., Self, S., Karlstrom, L., Renne, P.R., Manga, M., Sprain, C.J., Smit, J., Vanderkluysen, L., Gibson, S.A., 2015. Triggering of the largest Deccan eruptions by the Chicxulub impact. Geol. Soc. Am. Bull. 127, 1507-1520. https:// doi.org/10.1130/B31167.1.

Rindraharisaona, E.J., Guidarelli, M., Aoudia, A., Rambolamanana, G., 2013. Earth structure and instrumental seismicity of Madagascar: implications on the seismotectonics. Tectonophysics 594, 165-181. https://doi.org/10.1016/j.tecto.2013. 03.033.

Rossum, G., 1995. Python Reference Manual. CWI (Centre for Mathematics and Computer Science), Amsterdam, The Netherlands.

Saria, E., Calais, E., Stamps, D.S., Delvaux, D., Hartnady, C.J.H., 2014. Present-day kinematics of the East African Rift. J. Geophys. Res. 119, 3584-3600. https:// doi.org/10.1002/2013JB010901.

Sauter, D., Cannat, M., Meyzen, C., Bezos, A., Patriat, P., Humler, E., Debayle, E., 2009 Propagation of a melting anomaly along the ultraslow Southwest Indian Ridge between $46^{\circ} \mathrm{E}$ and $52^{\circ} 20^{\prime} \mathrm{E}$ : interaction with the Crozet hotspot? Geophys. J. Int. 179, 687-699. https://doi.org/10.1111/j.1365-246X.2009.04308.x.

Savage, M.K., 1999. Seismic anisotropy and mantle deformation: what have we learned from shear wave splitting. Rev. Geophys. 17, 65-106.

Schaeffer, A.J., Lebedev, S., Becker, T.W., 2016. Azimuthal seismic anisotropy in the Earth's upper mantle and the thickness of tectonic plates. Geophys. J. Int. 207, 901-933. https://doi.org/10.1093/gji/ggw309.

Schlindwein, V., Schmid, F., 2016. Mid-ocean-ridge seismicity reveals extreme types of ocean lithosphere. Nature 536, 276-279. https://doi.org/10.1038/nature18277.

Schmid, F., Schlindwein, V., Koulakov, I., Plötz, A., Scholz, J.-R., 2017. Magma plumbing system and seismicity of an active mid-ocean ridge volcano. Sci. Rep. 7, 42949. https://doi.org/10.1038/srep42949.

Scholz, J.-R., Barruol, G., Fontaine, F.R., Sigloch, K., Crawford, W., Deen, M., 2017. Orienting ocean-bottom seismometers from P-wave and Rayleigh wave polarisations. Geophys. J. Int. 208, 1277-1289. https://doi.org/10.1093/gji/ggw426.

Sigloch, K., 2013. Short cruise report. METEOR Cruise 101, 1-9. https://doi.org/10. 2312/CR_M101.

Silver, P.G., Chan, W.W., 1991. Shear wave splitting and subcontinental mantle deformation. J. Geophys. Res. 96, 16429-16454.
Silver, P.G., Savage, M.K., 1994. The interpretation of shear-wave splitting parameters in the presence of two anisotropic layers. Geophys. J. Int. 119, 949-963.

Stähler, S.C., Sigloch, K., Hosseini, K., Crawford, W.C., Barruol, G., Schmidt-Aursch, M.C., Tsekhmistrenko, M., Scholz, J.-R., Mazzullo, A., Deen, M., 2016. Performance report of the RHUM-RUM ocean bottom seismometer network around La Réunion, western Indian Ocean. Adv. Geosci. 41, 43-63. https://doi.org/10.5194/ adgeo-41-43-2016.

Stamps, D.S., Iaffaldano, G., Calais, E., 2015. Role of mantle flow in NubiaSomalia plate divergence. Geophys. Res. Lett. 42, 290-296. https://doi.org/10. 1002/2014GL062515.

Tommasi, A., 1998. Forward modeling of the development of seismic anisotropy in the upper mantle. Earth Planet. Sci. Lett. 160, 1-13.

Vinnik, L., Romanowicz, B., Le Stunff, Y., Makeyeva, L., 1995. Seismic anisotropy in the $\mathrm{D}^{\prime \prime}$ layer. Geophys. Res. Lett. 22, 1657-1660. https://doi.org/10.1029/ 95GL01327.

Walker, K.T., Bokelmann, G.H., Klemperer, S.L., 2001. Shear-wave splitting to test mantle deformation models around Hawaii. Geophys. Res. Lett. 28, 4319-4322.

Wang, N., Montagner, J.-P., Fichtner, A., Capdeville, Y., 2013. Intrinsic versus extrinsic seismic anisotropy: the radial anisotropy in reference Earth models. Geophys. Res. Lett. 40, 4284-4288. https://doi.org/10.1002/grl.50873.

Wessel, P., Smith, W.H., Scharroo, R., Luis, J., Wobbe, F., 2013. Generic mapping tools: improved version released. Eos Trans. AGU 94, 409-410. https://doi.org/10.1002/ 2013 E0450001.

Wolfe, C.J., Silver, P.G., 1998. Seismic anisotropy of oceanic upper mantle: shear wave splitting methodologies and observations. J. Geophys. Res. 103, 749-771.

Wolfe, C.J., Solomon, S.C., 1998. Shear-wave splitting and implications for mantle flow beneath the MELT region of the East Pacific Rise. Science 280, 1230-1232.

Wüstefeld, A., Bokelmann, G., 2007. Null detection in shear-wave splitting measurements. Bull. Seismol. Soc. Am. 97, 1204-1211. https://doi.org/10.1785/ 0120060190 .

Wüstefeld, A., Bokelmann, G., Barruol, G., Montagner, J.-P., 2009. Identifying global seismic anisotropy patterns by correlating shear-wave splitting and surfacewave data. Phys. Earth Planet. Inter. 176, 198-212. https://doi.org/10.1016/j.pepi. 2009.05.006.

Wüstefeld, A., Bokelmann, G., Zaroli, C., Barruol, G., 2008. SplitLab: a shear-wave splitting environment in Matlab. Comput. Geosci. 34, 515-528. https://doi.org/ 10.1016/j.cageo.2007.08.002.

Yamamoto, M., Morgan, J.P., Morgan, W.J., 2007. Global plume-fed asthenosphere flow-II: application to the geochemical segmentation of mid-ocean ridges. In: Special Paper 430: Plates, Plumes and Planetary Processes. Geological Society of America, pp. 189-208. 